\title{
Integration of molecules and new fossils supports a Triassic origin for Lepidosauria (lizards, snakes, and tuatara)
}

Marc EH Jones ${ }^{1,2^{*}}$, Cajsa Lisa Anderson ${ }^{3}$, Christy A Hipsley ${ }^{4}$, Johannes Müller ${ }^{4,6}$, Susan E Evans ${ }^{1}$ and Rainer R Schoch ${ }^{5}$

\begin{abstract}
Background: Lepidosauria (lizards, snakes, tuatara) is a globally distributed and ecologically important group of over 9,000 reptile species. The earliest fossil records are currently restricted to the Late Triassic and often dated to 227 million years ago (Mya). As these early records include taxa that are relatively derived in their morphology (e.g. Brachyrhinodon), an earlier unknown history of Lepidosauria is implied. However, molecular age estimates for Lepidosauria have been problematic; dates for the most recent common ancestor of all lepidosaurs range between approximately 226 and 289 Mya whereas estimates for crown-group Squamata (lizards and snakes) vary more dramatically: 179 to 294 Mya. This uncertainty restricts inferences regarding the patterns of diversification and evolution of Lepidosauria as a whole.
\end{abstract}

Results: Here we report on a rhynchocephalian fossil from the Middle Triassic of Germany (Vellberg) that represents the oldest known record of a lepidosaur from anywhere in the world. Reliably dated to 238-240 Mya, this material is about 12 million years older than previously known lepidosaur records and is older than some but not all molecular clock estimates for the origin of lepidosaurs. Using RAG1 sequence data from 76 extant taxa and the new fossil specimens two of several calibrations, we estimate that the most recent common ancestor of Lepidosauria lived at least 242 Mya (238-249.5), and crown-group Squamata originated around 193 Mya (176-213).

Conclusion: A Early/Middle Triassic date for the origin of Lepidosauria disagrees with previous estimates deep within the Permian and suggests the group evolved as part of the faunal recovery after the end-Permain mass extinction as the climate became more humid. Our origin time for crown-group Squamata coincides with shifts towards warmer climates and dramatic changes in fauna and flora. Most major subclades within Squamata originated in the Cretaceous postdating major continental fragmentation. The Vellberg fossil locality is expected to become an important resource for providing a more balanced picture of the Triassic and for bridging gaps in the fossil record of several other major vertebrate groups.

Keywords: Dating, Fossil, Jurassic, Lepidosauria, Lizards, Molecular, Origin, Squamata, Triassic, Tuatara

\footnotetext{
* Correspondence: marc.jones@adelaide.edu.au

${ }^{1}$ Research Department of Cell and Developmental Biology, Anatomy

Building, UCL, University College London, Gower Street, London WCIE 6BT,

UK

${ }^{2}$ School of Earth and Environmental Sciences, The University of Adelaide,

North Terrace, Adelaide, South Australia 5005, Australia

Full list of author information is available at the end of the article
} 


\section{Background}

Lepidosauria (lizards, snake, tuatara) currently have a global distribution, encompass $>9000$ species, and fill a variety of ecological niches [1,2]. The vast majority of this diversity comprises lizards and snakes (Squamata). By contrast, their sister group, Rhynchocephalia, is represented by a single extant species, Sphenodon punctatus, the New Zealand tuatara [3,4]. The fossil record suggests for the first half of the Mesozoic, Rhynchocephalia was the more successful lepidosaur group but the earliest history of Lepidosauria remains incompletely known [5-10]. An accurate estimate for when this clade originated is crucial for appreciating the ecological context in which it first evolved in addition to its subsequent diversification. Currently, the oldest fossil records of Lepidosauria are rhynchocephalian and Late Triassic in age (228-235 Mya, Carnian): Brachyrhinodon from the Lossiemouth Sandstone Formation of Scotland, UK [11], and a partial jaws from the Vinita Formation (previously the 'Turkey Branch'), Virginia, USA ([12,13], specimen figured in [14]) that include material reported to resemble Diphydontosaurus from the Late Triassic of England [12,15]. Now that Tikiguania [16] is considered to be modern rather than Late Triassic in age [17] the earliest putative squamate fossils are from the Early Jurassic of India [18]. However, as rhynchocephalians were present in the Late Triassic, stem lineage representatives of their sister taxon Squamata must also have been present concurrently [9].

Problematically, the earliest known lepidosaurs are already derived in several aspects of their anatomy [9]. Cladistic analyses consistently nest Brachyrhinodon amongst derived rhynchocephalians [19-21]. Diphydontosaurus is one of the least phylogenetically nested rhynchocephalians, but the stout teeth with prominent radial ridges of the Vinita specimen [14] suggest a closer affinity to the more derived Planocephalosaurus from the Late Triassic of the UK [22]. Also other slightly younger Late Triassic Rhynchocephalia are both widespread and diverse [5,10,23-25]. Hence, the success of Late Triassic Rhynchocephalia suggests either a rapid diversification of the clade or alternatively an older unknown history during the Early and Middle Triassic [24-26]. Unfortunately, this crucial interval remains cryptic due to the rarity of fossil deposits of the correct age and with suitable preservational potential for small vertebrates [5,9].

Until recently, the record of stem-lepidosaurs was not very helpful to the question of lepidosaur origins [5]. Paliguana from the Early Triassic of South Africa is from the appropriate time interval but the specimen is badly damaged and provides little data $[9,27]$. The aquatic Marmoretta (Middle Jurassic of the UK, $[26,28]$ ), parachuting/gliding kuehneosaurs (Late Triassic of USA and the UK, $[29,30])$, and burrowing Tamaulipasaurus (Early Jurassic of Mexico, [31]) are all younger than or coeval with the oldest lepidosaurs. The Middle Triassic Megachirella [32] is older but of questionable affinity [5]. The newly described kuehneosaur Pamelina [33] and the less specialised Sophineta [34] from the Early Triassic of Poland confirm that stem-lepidosaurs were present and had diversified by at least the Early Triassic.

Aside from fossils, molecular dating provides a complimentary means of estimating the origin of Lepidosauria. Initial calculations by Kumar and Hedges [35] based on amino acid sequences provided a broad estimate of 276 \pm 54.4 Mya located deep within the Permian (Table 1, Additional file 1). Several subsequent analyses using more recent methods have also recovered estimates from within the Permian, 289 and 265 Mya [36-39]. However, other molecular dating analyses provide dates in the Late or Middle Triassic with one as recent/shallow as 226 Mya [39-43]. This range of estimates is far more disparate than those based on the fossil record and morphological characters which suggest an Early to Middle Triassic origin time (e.g. $[9,26])$. Although the lizard-tuatara node was not listed as a potential calibration for the animal tree of life by Benton \& Donoghue [44], it was by Benton [45], and some analyses have used the earliest currently known lepidosaur fossils to constrain divergence times for investigating the origins of both squamates and amniotes $[37,38,40-43]$. Despite uncertainty regarding the exact age of the Lossiemouth Sandstone Formation and the likely older Vinita Formation (e.g. [11,13]), the date of 227 or $228 \mathrm{Mya}$ is often used (e.g. [41,42]) or suggested [45]. One recent analysis [43] used 222.8 Mya based on dates for the Upper-Carnian boundary found in Gradstein et al. [46]. However, revised stratigraphic work suggests the age of this boundary is older [47].

The origin time of crown-group Squamata (all living squamates and their most recent common ancestor) has received an even greater degree of attention [3,36-39, $41,43,48-51,53]$. Squamates are an ecologically important component of our modern fauna but the timing and thus ecological context of their initial evolution remains poorly understood $[5,6,9]$. Current estimates for crown-group squamate origins vary by 120 million years (Table 1) with the oldest/deepest date being 294 Mya [48] and most recent/shallow being 179 Mya [41]. This represents a 60\% difference between these two points in time (Early Permian or Early Jurassic), when many aspects of the biosphere were radically different: continental distributions, palaeoclimates, vegetation, macrofaunas, and potential prey and predator species (e.g. [47,54-62]). Moreover, these two estimates straddle the end Permian and (less well understood) end Triassic mass-extinction events, both of which significantly impacted terrestrial vertebrate communities (e.g. [47,54,57,63-68]).

Constraining the origination times of Lepidosauria and crown-group Squamata is also important for evaluating 
Table 1 Summary of previous molecular divergence estimates

\begin{tabular}{|c|c|c|c|c|c|}
\hline Analysis & Material & $\begin{array}{c}\text { No. of } \\
\text { squamate taxa }\end{array}$ & $\begin{array}{l}\text { Dating software } \\
\text { and/or method }\end{array}$ & $\begin{array}{l}\text { Age crown } \\
\text { Lepidosauria }\end{array}$ & $\begin{array}{l}\text { Age crown } \\
\text { Squamata }\end{array}$ \\
\hline Albert et al. [38] & mtDNA (13 genes) & 27 & r8s, Penalized Likelihood & $289 \pm 5$ & 281 \\
\hline Albert et al. [38] & mtDNA (13 genes) & 27 & $\begin{array}{l}\text { "Multidivtime", Bayesian } \\
\text { autocorrelated clock }\end{array}$ & $272 \pm 20$ & 259 \\
\hline Alfaro et al. [3] & nDNA: RAG-1 & 35 & $\begin{array}{l}\text { BEAST, Bayesian uncorrelated } \\
\text { lognormal clock }\end{array}$ & $246(208-275)$ & mid TR - mid JU \\
\hline Gorr et al. [40] & a haemoglobin chains & $3 \mid 6$ & $\begin{array}{l}\text { Strict clock (least-squares } \\
\text { regression) }\end{array}$ & 233 & $\mathrm{n} / \mathrm{a}$ \\
\hline Gorr et al. [40] & $\beta$ haemoglobin chains & 9 & $\begin{array}{l}\text { Strict clock (least-squares } \\
\text { regression) }\end{array}$ & 226 & $\sim 194$ \\
\hline Hipsley et al. [42] & mtDNA and nDNA (5 genes) & $40^{1}$ & $\begin{array}{l}\text { TreeTime, Bayesian uncorrelated } \\
\text { lognormal clock }\end{array}$ & $238 \pm 10$ & $\mathrm{n} / \mathrm{a}$ \\
\hline Hugall et al. [36] & nDNA: RAG-1 & 36 & r8s, Penalized Likelihood & $250-268 \pm 12^{2}$ & $171-190^{*} \pm 14$ \\
\hline Hugall et al. [36] & nDNA: RAG-1, translated & 36 & r8s, Penalized Likelihood & $261-275 \pm 17^{2}$ & $184-201^{*} \pm 19$ \\
\hline Janke et al. [48] & mtDNA & 2 & Strict clock (after pruning of taxa) & $\mathrm{n} / \mathrm{a}$ & $294^{3}$ \\
\hline Kumar and Hedges [35] & Amino acid sequences (5 genes) & $?$ & $\begin{array}{l}\text { Strict clock (after pruning of } \\
\text { heterogeneous sequences) }\end{array}$ & $276 \pm 54.4$ & $\mathrm{n} / \mathrm{a}$ \\
\hline Kumazawa [37] & mtDNA & 24 & $\begin{array}{l}\text { "Multidivtime", Bayesian } \\
\text { autocorrelated clock }\end{array}$ & $\sim 260-290$ & $\sim 215-255$ \\
\hline Mulcahy et al. [43] & mtDNA and nDNA (RAG-1) & 64 & $\begin{array}{l}\text { BEAST, Bayesian uncorrelated } \\
\text { lognormal clock }\end{array}$ & $\sim 233(223-243)$ & $180(160-198)$ \\
\hline Mulcahy et al. [43] & mtDNA and nDNA (RAG-1) & 64 & r8s, Penalized Likelihood & $\sim 275$ (na) & $191.8(186-194)$ \\
\hline Okajima \& Kumazawa [49] & mtDNA & 22 & $\begin{array}{l}\text { "Multidivtime", Bayesian } \\
\text { autocorrelated clock }\end{array}$ & $\mathrm{n} / \mathrm{a}$ & $240(220-260)$ \\
\hline Pyron [39] & nDNA: RAG-1 ${ }^{4}$ & 44 & $\begin{array}{l}\text { BEAST, Bayesian uncorrelated } \\
\text { lognormal clock }\end{array}$ & $236(212-253)$ & $189(163-213)$ \\
\hline Pyron [39] & nDNA: RAG-1 ${ }^{5}$ & 44 & $\begin{array}{l}\text { BEAST, Bayesian uncorrelated } \\
\text { lognormal clock }\end{array}$ & $265(240-290)$ & $208(179-234)$ \\
\hline Shen et al. [50] & mtDNA and nDNA & 5 & $\begin{array}{l}\text { "Multidivtime", Bayesian } \\
\text { autocorrelated clock }\end{array}$ & $\mathrm{n} / \mathrm{a}$ & 205 (180-228) \\
\hline Vidal and Hedges [51] & nDNA: C-mos, RAG-1 & 19 & $\begin{array}{l}\text { "Multidivtime", Bayesian } \\
\text { autocorrelated clock }\end{array}$ & $<251$ & $240(221-251)$ \\
\hline Wiens et al. [41] & nDNA: RAG-1 ${ }^{6}$ & $261^{7}$ & r8s, Penalized Likelihood & $227^{8}$ & $179 \pm 5.5$ \\
\hline
\end{tabular}

Annotations: ${ }^{1}$ focused on lacertids, ${ }^{2}$ range of four different estimates provided by varying the number of calibration points, ${ }^{3}$ Sphenodon was not included amongst the taxa therefore the estimate better corresponds to one for Lepidosauromorpha, ${ }^{4}$ four fossil calibrations from Müller and Reisz [52], ${ }^{5}$ five fossil calibrations from Hugall et al. [36], ${ }^{6}$ supertree approach, ${ }^{7}$ focused on taxa with a snake-like bodyform, ${ }^{8}$ used as fixed calibration point. Abbreviations: JU Jurassic, TR Triassic.

divergences within Squamata and for improving the accuracy of molecular dating analyses for the group as a whole (e.g. $[39,43])$. It has been shown that the most important factor for improving molecular age estimates is the amount and quality of age constraints (e.g. [69-71]), and studies assessing the relationship between historical events and biological evolution (e.g. clade divergence, adaptive radiations, biogeography, species richness patterns) rely on date constraints being accurate (e.g. [3,42,72-74]). The discovery of any Early or Middle Triassic lepidosaur fossil material would clearly have implications for the ages of early lepidosaur divergences and associated evolutionary history.

Here we report a new rhynchocephalian from the Middle Triassic of Germany (240 Mya) that predates previously known lepidosaur material by about 12 million years. We describe the two partial dentaries in detail and include them in a cladistic analysis based on both old and new morphological characters to test their lepidosaur affinities. We also carry out a molecular divergence analysis using the new fossil and 13 other reliable amniote fossils, to provide a new framework for divergence times for Lepidosauria, Squamata, and subgroups within the latter.

\section{Institutional abbreviations}

SMNS, Staatliches Museum für Naturkunde, Stuttgart, Baden-Württemberg, Germany.

\section{Methods}

The new fossil material described here comprises two partial dentaries: a right bone exposed in lateral view 
bearing six teeth (SMNS 91060) and a left bone exposed in lingual view bearing two large teeth posteriorly and at least seven distinctly smaller teeth anteriorly (SMNS 91061).

\section{Geographic and stratigraphic provenance}

Both specimens were found in the same 50-100 mm thick mudstone layer at the top of the Untere Graue Mergel (lower grey marls) of the Lower Keuper (Erfurt Formation) (Figure 1). This corresponds to layer 6 of Schoch [75] which is known only from the Vellberg locality, southern Germany. Cyclostratigraphic data [76] suggests the Erfurt Fm is between 239 and 240 Mya which corresponds to the Ladinian part of the Middle Triassic [47,77]. Kozur and Bachman [78] suggest a slightly earlier date of 238-238.8 Mya for this unit based on zircon $\mathrm{U}-\mathrm{Pb}$ dating.

The locality preserves deposits from a freshwater lake a few kilometers in diameter. Contemporaneous exposures in the vicinity lack layer 6 and show evidence for large brackish swamps instead. The local fauna was diverse and included actinopterygians, lungfishes, coelacanths, temnospondyls, sauropterygians, and archosaurs of various sizes [75,79-88]. Local climate was probably monsoonal including both dry and humid intervals $[89,90]$.

\section{Morphological examination}

Specimens were examined using a Wild stereobinocular microscope and drawn using a camera lucida attachment. Specimen SMNS 91060 was also examined using a JEOL JSM-5410LV Scanning Electron Microscope in the Research Department of Cell and Developmental Biology at University College London. Both specimens were scanned using a X-Tek HMX 160 micro CT scanner in the Department of Engineering at the University of Hull using the following parameters: scan energy 80kV, uA 22 (SMNS 91060) and uA 20 (SMNS 91061), aperture 75\%, 1000 projections averaging 16 frames per projection. To reduce beam hardening the $\mathrm{x}$-rays were filtered through a $0.1 \mathrm{~mm}$ copper plate. Voxel resolution was $0.0227 \mathrm{~mm}^{3}$ for SMNS 91060 and 0.0374 $\mathrm{mm}^{3}$ for SMNS 91061. The CT models (Additional files 2, 3 and Additional file 1: Figure S1.1) were constructed using the software Amira 4.1 (Mercury Computer Systems Inc, USA).

\section{Phylogenetic placement of the Vellberg fossils}

Twenty-two taxa were used for phylogenetic assessment of the Vellberg jaws. Of these, 20 are fossil taxa, 15 represent ingroup taxa and 7 outgroup taxa (Additional file 1). Squamata was used as a metataxon because the early fossil record of this group remains poor. Modern examplar taxa were not used to represent Squamata, because within this diverse group it is uncertain what the plesiomorphic states are and which taxa would best represent the group as a whole.

The 22 taxa were coded using 100 characters. Many of the characters have a long history of usage in cladistic studies and date back to work by Evans [91,92], Whiteside [15], Benton [93] and Gauthier et al. [94]. Others characters include those that were added and modified during a number of subsequent studies (e.g. [11,19-21]). Characters 1 to 77 (see Additional file 1) broadly correspond to those used by Evans [33] and Evans and Borsuk-Bialynicka [34]. These were in error said to be listed in Waldman and Evans [28] but in actuality refer to part of the analysis that was removed prior to publication.

Despite the number of characters used in previous analyses, this matrix should be treated as new because several characters have been modified to accommodate both rhynchocephalians and stem group lepidosauromorphs.

The data matrix was analyzed using PAUP* $4.0 \mathrm{~b} 10$ [95] and MrBayes [96]. All characters were equally weighted and unordered. In the few cases where taxa exhibited multiple states for the same character, the state was treated as uncertain (by default, PAUP* treats uncertain multistate characters as polymorphism, whilst MrBayes treats them as total uncertainty, which could potentially lead to larger differences in inferred trees if the matrix contains many multiple state characters). Petrolacosaurus was used as the outgroup. Bootstrap support for clades found by PAUP* were calculated from 1000 replicates of heuristic search using TBR and random addition. MrBayes was run for 1 million generations with sample frequency 1000, 3 runs with 4 chains each, and the majority rule consensus tree was calculated after a $50 \%$ burnin. For characters and matrix, see Additional file 1. The matrix is also deposited in the Dryad data repository (http://datadryad.org/), with the Digital Object Identifier (DOI) of http://dx.doi.org/ 10.5061/dryad.gr573

\section{Molecular divergence dating}

We compiled a dataset of RAG1 nuclear gene sequences from GenBank for 76 extant amniote taxa (Additional file 4). This comprised Sphenodon punctatus (Rhynchocephalia), 62 lizards and snakes (Squamata), four Testudines, four Aves and three Crocodylia (see Additional file 4). Two mammals (one marsupial and one monotreme) served as outgroups. Sequences were aligned using the ClustalW option in SeaView [97].

For choosing the molecular substitution model we analysed the data using MrModelTest v2 [98], and based on the Akaike Information Criterion, the most parameterrich model GTR+G+I was suggested. However, we chose the less complex model $\mathrm{GTR}+\mathrm{G}$, because although 


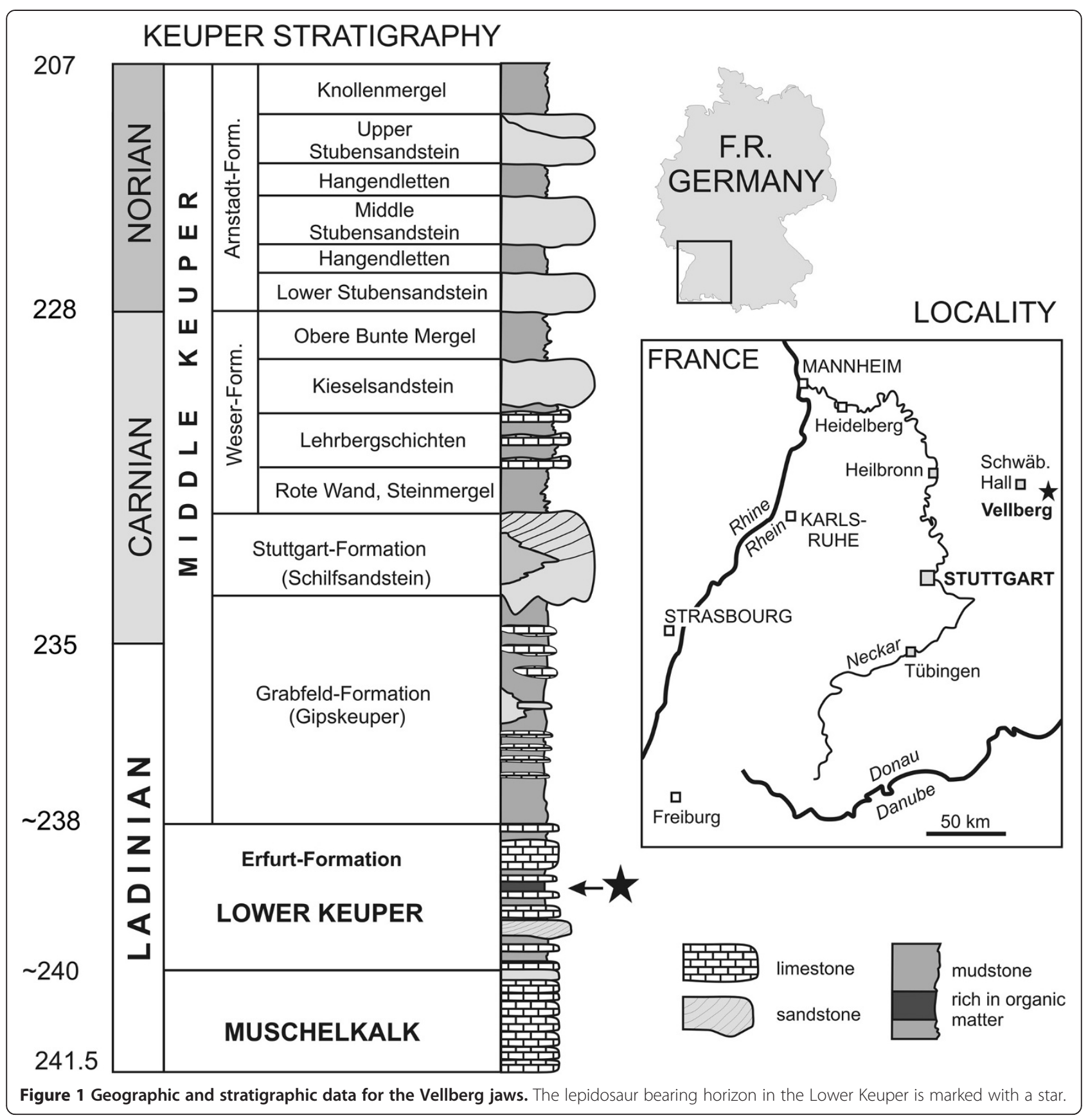

GTR+G+I would improve the model's fit to the data it also seems to cause convergence difficulties rather than improving the phylogenetic reconstruction and dating. Several studies have shown that the gamma shape parameter and the invariant sites parameter are highly correlated and even considered to be "pathological" when estimated together $[99,100]$. The combination of $\mathrm{G}+\mathrm{I}$ can overestimate the rate of molecular evolution and, consequently, affect the estimation of divergence times.

For phylogenetic reconstruction and divergence time estimation, the BEAST [101] software package (version
1.7.3) was used. The methods implemented in BEAST make it possible to infer tree topology simultaneously with ages. However, as our data set contains a large number of fossil constraints as well as long branches / heterogeneous rates across the phylogeny, the initial UPGMA starting tree inferred by BEAST did not fit the data, causing the initial likelihood to be zero. This problem is solved by providing a starting tree that is fully bifurcating and not in conflict with the data and prior assumptions.

To obtain a starting tree we ran a MrBayes analysis [96] under the GTR+G model, three runs and three 
chains over five million generations. After discarding a burn in of $50 \%$ we filtered the output trees using PAUP* and a set of "soft" backbone constraints (polytomies representing uncertain parts of the topology), so that all trees were consistent with current knowledge of reptile phylogeny and that subtrees that need to be monophyletic for the calibration points were not violated. (For the unfiltered majority rule consensus tree with posterior probabilities, see Additional file 5.) One random tree from this set of filtered trees was used for dating using the penalized likelihood method (PL) implemented in the r8s software [102]. To obtain a starting tree for BEAST it was further necessary to heavily constrain the nodes in the PL analyses, and 6 fossils were used as both minimum (the fossil age) and maximum (the fossil age plus 20\%) ages.

For the final BEAST analysis the uncorrelated lognormally distributed clock model was used [103], with the Yule birth rate as the general tree prior.

In total 14 fossils were used to specify informative priors on internal node divergence times. These were chosen following the recommendations on fossil calibrations of Parham et al. [74]. Calibrated nodes are: (CNX) Archosauromorpha-Lepidosauromorpha, 255 Mya, based on Protorosaurus sp., the oldest known archosauromorph [104]; (CNY) Alligator-Passer montanus, 247 Mya (to 256 Mya), based on oldest known certain archosaur Ctenosauriscus koeneni [105]; (CN1) Sphenodon-Varanus (origin of Lepidosauria, the tuatata-lizard split) 238 Mya, based on the new fossil jaws described here; (CN2) Eublepharis-Sphaerodactylus (origin of Gekkonidae), 44 Mya, based on Yantarogekko balticus, the earliest certain gekkonid [106,107]; (CN3) Xantusia-Cordylus, 61 Mya, based on Palaeoxantusia fera, the earliest known xantusiid [47,108-110]; (CN4) Lacertidae-Amphisbaenia, 61 Mya, based on Plesiorhineura tsentasi, the earliest certain amphisbaenian [108-111]; (CN5) Python-Elgaria (SerpentesAnguimorpha), 148 Mya, based on Dorsetisaurus sp., the earliest known anguimorph [112-114]; (CN6) Varanus-Lanthanotus, 48 Mya, based on Saniwa ensidens an immediate sister taxon to Varanus [114-117]; (CN7) Heloderma-Anniella, 98 Mya, based on Primaderma nessovi which represents the oldest fossil taxon more closely related to Heloderma than to any other living taxon [114,118,119]; (CN8) Elgaria-Ophisaurus, 33 Mya, based on fossil material referable to Ophisaurus sp. from the UK $[47,120,121]$; (CN9) ChamaeleoCalumma, 19 Mya, based on fossil material referable to Chamaeleo sp. from the Czech Republic [122,123]; (CN10) Physignathus-Ctenophorus, 16 Mya, based on material referable to Physignathus sp. from Australia [124-126]; (CN11) Gambelia-Anolis, 48 Mya, based on Afairiguana avius the oldest pleurodontan iguanian $[117,118,127,128]$; and (CN12) Shinisaurus-Elgaria,
128 Mya, based on Dalinghosaurus longidigitus which may be more closely related to Shinisaurus than to any other living squamate $[114,129,130]$. For the full justification of each of the fossil specimens and their age see Additional file 1. We also ran three different schemes of fossil-based cross validations [131] on the 14 fossils used in the dating.

All fossils were used as a hard minimum age constraint to the node below the hypothesized branching of the fossil lineage. For the prior distributions of ages the exponential prior was used and the mean set consistently to 4.0 for all constraints (Table 2). In absolute ages this prior distribution means an age interval of about 15-20 million years, with low probability of being older. Monophyly of groups constrained by fossils was enforced.

Fifty million generations were run and logged every 1000 generations. Convergence and effective sample size (ESS) for parameters were checked with Tracer (version $1.5)$, with a burn in of $10 \%$. For further confirmation of convergence, the analysis was run several times, with identical settings as well as slightly different values for the operators. Median ages and credibility intervals (CI) were calculated using TreeAnnotator. The XML-file for the BEAST analysis as well as the RAG1 nexus alignment are deposited in the Dryad data repository (http:// datadryad.org/), with the DOI of http://dx.doi.org/ 10.5061/dryad.gr573.

\section{Results}

\section{Systematic palaeontology}

Lepidosauria Haeckel [132] sensu Gauthier et al. [94]. Rhynchocephalia Günther [133] sensu Gauthier et al. [94]. cf. Diphydontosarus sp.

\section{Vellberg jaws - description}

Although incomplete, the dentaries are well preserved. The first specimen (SMNS 91060) bears six laterally compressed teeth that are triangular in lateral profile, sit on the crest of the jaw bone (acrodont implantation), and are fused so that the boundary between tooth and jaw bone is indistinct (Figure 2A; Additional file 2). The remains of a smaller seventh tooth are present anteriorly but it is broken. The dentary extends posteriorly beyond the tooth row and expands dorsally so that the dorsoventral height of the element is twice that of the available anterior end. Six ovoid foramina lie beneath the tooth row along the jaw labially. The Meckelian canal is open and located at a level midway between the tooth row and ventral margin of the jaw.

The second specimen (SMNS 91061) shows evidence of two acrodont teeth: the posteriormost tooth is missing, but the surrounding matrix bears a clear impression 
Table 2 Summary of the prior and posterior ages for the constrained nodes

\begin{tabular}{|c|c|c|c|c|c|}
\hline $\begin{array}{c}\text { Constrained } \\
\text { nodes }\end{array}$ & Split & $\begin{array}{l}\text { Minimum age of } \\
\text { fossil constraint }\end{array}$ & $\begin{array}{c}\text { Median posterior } \\
\text { (calculated age) }\end{array}$ & $\begin{array}{c}95 \% \text { HPD } \\
\text { lower }\end{array}$ & $\begin{array}{c}95 \% \text { HPD } \\
\text { upper }\end{array}$ \\
\hline$x$ & Archosauromorpha-Lepidosauromorpha & 255 & 271 & 259 & 285.2 \\
\hline Y & Crown Archosauria sensu stricto & 247 & 248.3 & 247 & 252.8 \\
\hline 1 & Sphenodon-Varanus (Lepidosauria) & 238 & 240.8 & 238 & 249.6 \\
\hline 2 & Eublepharis-Sphaerodactylus (Gekkonidae) & 44 & 50.5 & 44 & 63.3 \\
\hline 3 & Xantusia-Cordylus & 61 & 67 & 61 & 84.3 \\
\hline 4 & Lacertidae-Amphisbaenia & 61 & 66.1 & 61 & 80.9 \\
\hline 5 & Python-Elgaria (Anguimorpha) & 148 & 150.3 & 148 & 156.8 \\
\hline 6 & Varanus-Lanthanotus & 48 & 50.5 & 48 & 58.3 \\
\hline 7 & Heloderma-Anniella & 98 & 100.4 & 98 & 108 \\
\hline 8 & Elgaria-Ophisaurus & 33 & 35.3 & 33 & 42.1 \\
\hline 9 & Chamaeleo-Calumma (chameleons) & 19 & 21.8 & 19 & 29.6 \\
\hline 10 & Physignatus-Ctenophorus & 16 & 18.9 & 16 & 26.9 \\
\hline 11 & Gambelia-Anolis & 48 & 50.5 & 48 & 58 \\
\hline 12 & Shinisaurus-Elgaria & 128 & 129.6 & 128 & 134.4 \\
\hline
\end{tabular}

The minimum ages of the fossils were used as hard bounds, and prior ages set as exponentially distributed with a mean $=4.0$. The posterior (calculated) ages are listed as median, 95\% HDP lower and 95\% HDP upper.

of a mediolaterally compressed cone, and an ovoid base is clearly visible in dorsal view (Figure 2B; Additional file 4: Video S4). The two posterior teeth are preceeded by seven teeth which are smaller and more columnar. These latter teeth are less clearly fused to the bone, sit against a low labial wall (weak pleurodont implantation). Anterior to these seven teeth is a short series of small teeth that appear to have coalesced. In rhynchocephalians and some derived squamates with acrodont teeth, new teeth are added to the rear of the jaw with growth (e.g. [23,134]). Therefore, differences in the number of large posterior teeth may relate to ontogeny and both specimens probably
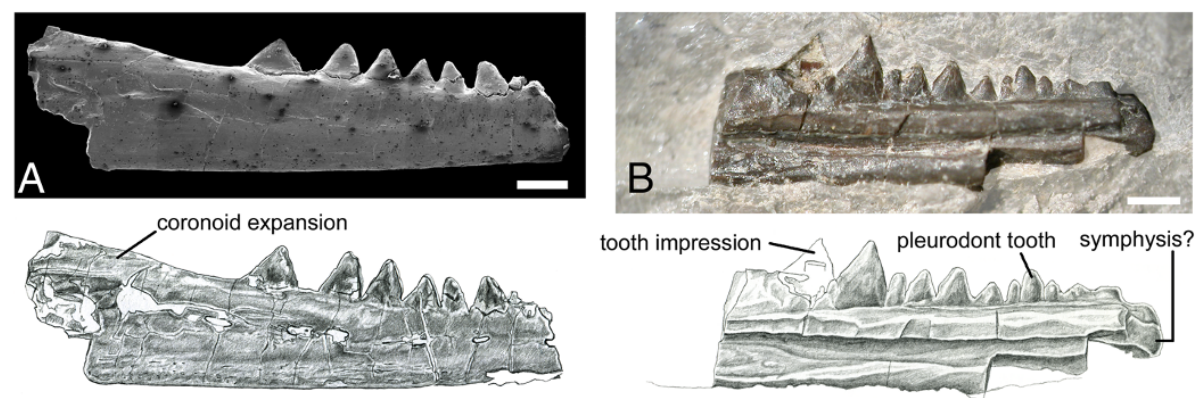

tooth impression pleurodont tooth symphysis?
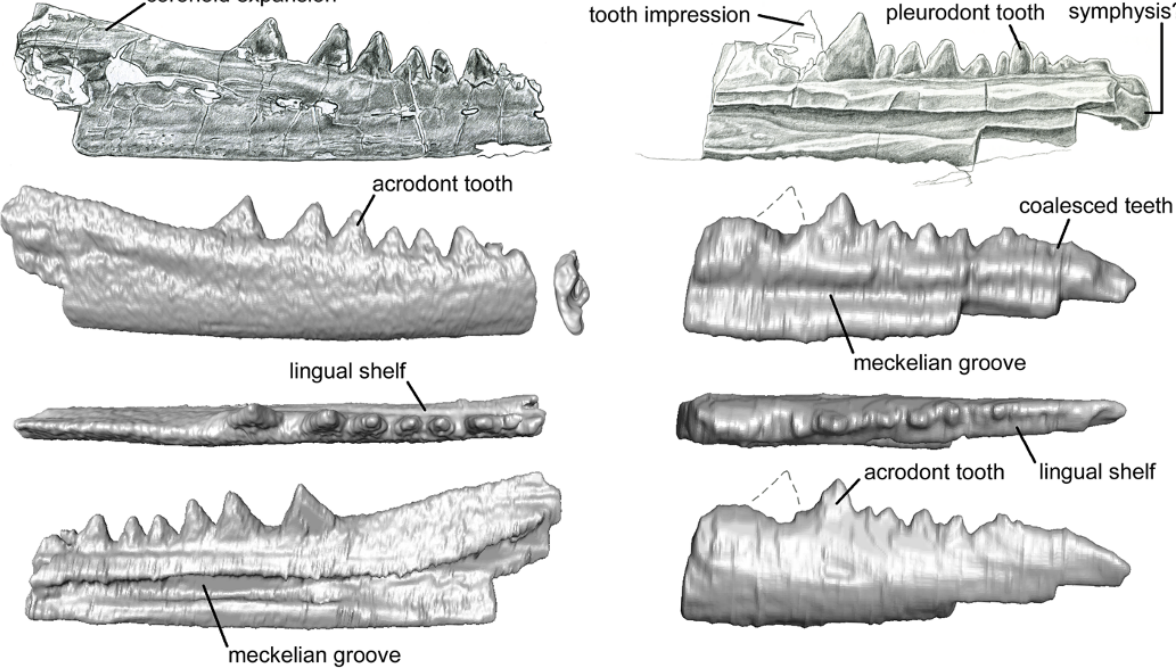

Figure 2 Partial rhynchocephalian dentaries from the Vellberg locality of Germany. A. Dentary SMS 91060. From top to bottom: SEM of labial aspect, drawing of labial aspect, CT model in labial, dorsal and lingual view. B. Dentary SMS 91061. From top to bottom: photo of lingual aspect, drawing of lingual aspect, CT model in lingual, dorsal and labial view. Scale bars equal $1 \mathrm{~mm}$. 
represent the same taxon (Additional file 1: Figure S1.2). The anterior end of this second dentary is rounded and may represent part of the symphysial region. If this is correct, it suggests that an adult animal possessed about 14 teeth with an equal number of acrodont and subpleurodont teeth. A facet for a splenial does not appear to be present and the Meckelian canal is similar in position to that of SMNS 91060.

In both specimens, a shelf is present lingual to the base of the tooth row and this diminishes posteriorly. The teeth lack any obvious ornamentation or ridging.

\section{Comparisons with other taxa}

The jaws of stem-lepidosaurs are gracile and bear large numbers of small, weakly implanted acuminate teeth $[28,33,34]$. In contrast, the Vellberg dentaries demonstrate several features supporting attribution to Lepidosauria and, more particularly, Rhynchocephalia, including possession of a coronoid expansion and a lingual subdental shelf [34]. As in rhynchocephalians with presumed plesiomorphic characters, such as Gephyrosaurus from the Early Jurassic of Wales (UK) [91,135], the dentition is regionalised into anterior and posterior series based on tooth size, shape and implantation [15]. The posterior teeth are larger than the anterior teeth, labiolingually compressed and triangular in profile, sit on the crest of the jaw bone (acrodonty), and are fused so that the boundary between tooth and bone is indistinct (Figure 2A, B). The anterior teeth are smaller, more columnar in shape, and sit against a low labial wall (weakly pleurodont) (Figure 2B). Both acrodonty and pleurodonty are derived character states of lepidosaurs $[9,34]$, but only rarely do they occur together: the Vellberg jaws, Diphydontosaurus, reportedly Whitakersaurus from the Late Triassic of USA [24], and some agamid lizards (e.g. [134]). Two further characters of the dentition support attribution to Rhynchocephalia. The first is the apparent absence or slow pace of tooth replacement, as evidenced by the lack of gaps in the tooth row $[34,91,135]$. The second is the apparent coalescence of the anteriormost teeth (Figure 2B), a feature reminiscent of rhynchocephalians crownward of Diphydontosaurus that lay down additional hard tissues around teeth during life (e.g. $[23,136])$

Phylogenetic affinity within Rhynchocephalia is harder to determine. Assuming the anterior end of the dentary is present, the tooth number (about 14) is less than that found in Gephyrosaurus (30-40), Diphydontosaurus (20-25), Whitakersaurus $(18-<20)$, and a juvenile animal from the Late Triassic of Italy referred to Diphydontosaurus [15,24,91,137]. Tooth number is more similar to Planocephalosaurus $(<15)$, but this taxon has stouter teeth and a characteristically large posterior tooth bearing an incipient flange [22]. The teeth of the Vellberg specimens lack the striations apparent in the Vinita specimen [14] and reported in Whitakersaurus, as well as the flanges or obvious wear facet of derived rhynchocephalians such as clevosaurs, eilenodontines, and sphenodontines [10,136,138]. Another character often found in derived rhynchocephalians but absent from the Vellberg jaws is a labial skirt of secondary bone running along the dentary $[15,136]$. Overall, observations support the attribution of the Vellberg jaws to Rhynchocephalia in a phylogenetic position close to that of Diphydontosaurus or the less well known Whitakersaurus.

Two other groups of Triassic reptiles possess teeth that are acrodont and strongly fused: trilophosaurs and procolophonids [139,140]. However, the Vellberg jaws differ from those of either group in several ways. The teeth lack the ventral constriction, bulbous nature and slightly raised base often found in trilophosaur and procolophonid teeth $[140,141]$; they are not transversely expanded or separated by slot-like gaps [140-144]; and the slender elongate build of the Vellberg jaws is also inconsistent with their identification as procolophonid [139]. A procolophonid jaw has been described from Vellberg [84] and in contrast to the lepidosaur specimens this specimen exhibits a steeply rising coronoid process, bulbous teeth with ridged tooth tips, and a mesiodistal base dimension of $>2 \mathrm{~mm}$.

\section{Vellberg jaws - morphology based phylogenetic analysis}

The phylogenetic analysis employing 100 morphological characters and 22 taxa places the Vellberg jaws within Lepidosauria and Rhynchocephalia, confirming that these jaws represent the earliest known lepidosaur material. PAUP* and MrBayes gave essentially the same topology with a small difference in resolution, which was expected as the prior assumptions for morphological characters approximate parsimony. The phylogeny with bootstrap support and posterior probability values, as well as indication of the nodes where the methods give different resolution, is given in Figure 3.

The Bayesian analysis places Gephyrosaurus as the sister taxon to the remaining genera in Rhynchocephalia, but with poor support (posterior probability of 0.65). Diphydontosaurus, Whitakersaurus, and the Vellberg jaw are placed in a polytomy with a well supported monophyletic clade of more derived rhynchocephalians. The lack of resolution at this node is not surprising, as the Vellberg material and Whitakersaurus can only be coded for a relatively small number of jaw characters and several of those features represent synapomorphies for Rhynchocephalia as a whole. Within the derived group, Planocephalosaurus is well supported as sister taxon to the rest, followed by Clevosaurus. The Jurassic pleurosaurs, Palaeopleurosaurus and Pleurosaurus, are recovered as sister taxa but resolution between the remaining core taxa is otherwise poor. 


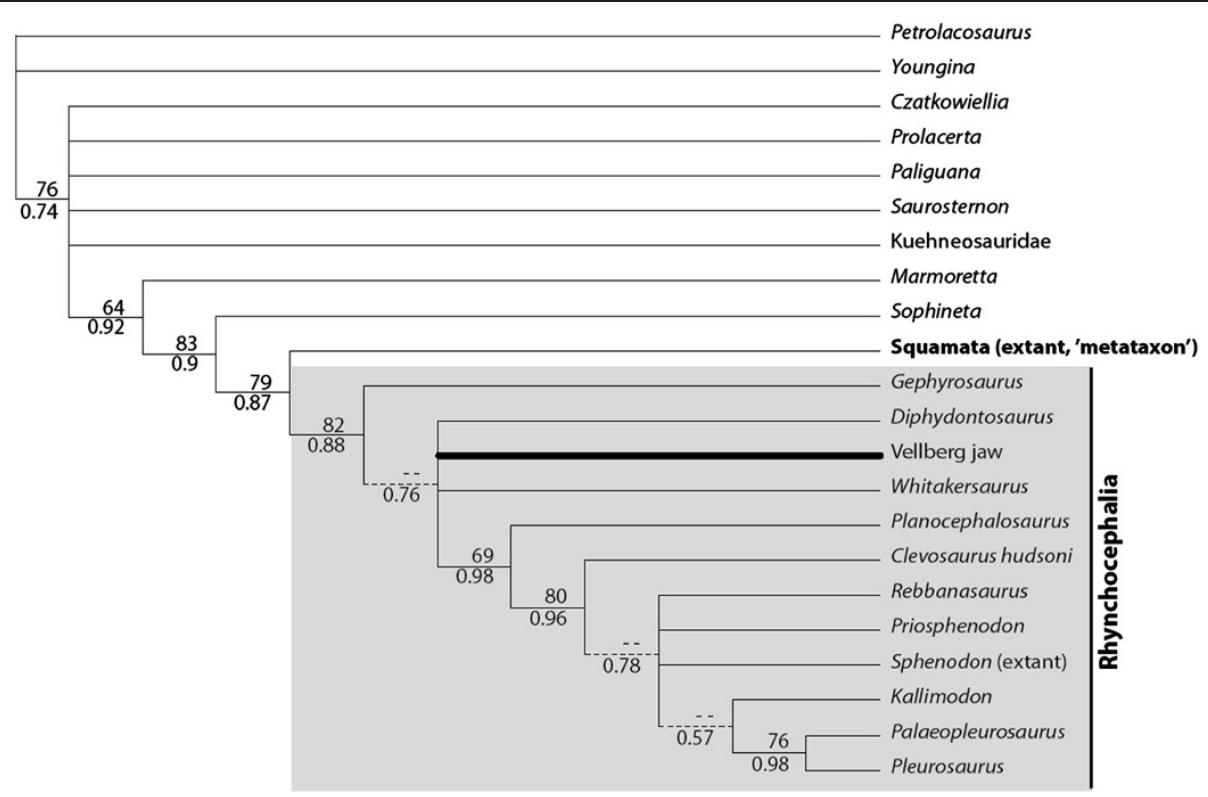

Figure 3 Phylogenetic relationships of the fossil jaws based on morphological data from living and extinct taxa. 50\% majority rule consensus tree inferred by MrBayes 3.1. Numbers below lines denote posterior probabilities. Numbers above lines denote bootstrap support values obtained from 1000 bootstrap replicates using parsimony criterion in PAUP*. Dashed lines indicate branches found by MrBayes but collapsed in the parsimony analysis, i.e. have less than $50 \%$ bootstrap support.

Derived characters that support the inclusion of the Vellberg jaws within Lepidosauria include (character number and coding according to matrix, see Additional file 1): anterior marginal teeth located against a prominent labial wall (pleurodonty): 40(2); the presence of obvious dental regionalisation into anterior and posterior sections: 85(1); posterior marginal teeth with no obvious boundary between tooth and bone: $87(2)$; anterior marginal teeth with slow tooth replacement (spaces and tooth replacement pits rare, tips may be worn): $88(1)$; posterior marginal teeth with no evidence of tooth replacement (no spaces, teeth often clearly worn): 89(2); posterior marginal teeth located on the crest of the jaw bone (acrodonty): 90(3); lingual subdental shelf present anteriorly: 91(1); coronoid process of the dentary with some expansion: 93(1). Four of these characters; 87(2), 88(1), 89(2), and 90(3), also secure the jaws within Rhynchocephalia.

\section{Lepidosauria - phylogenetic topology}

The topology obtained from our molecular divergence dating in the BEAST analysis (Figure 4: maximum clade credibility tree) is generally the same as that found by previous studies based on molecular data (e.g. $[41,51,145])$ : Lepidosauria is monophyletic, Gekkota is the sister taxon to all other Squamata, amphisbaenians are nested within Lacertoidea, and Iguania is sister group to Serpentes +
Anguimorpha. However, there are there are areas of disagreement some with two recent major studies: Townsend et al. [146] and Pyron et al. [2].

Townsend et al. [146], focus on phylogenetic relationships within iguanians using a greater number of taxa (47 vs 20 ) and additional genetic data (29 gene regions vs 1 ). In contrast to our analysis, this study recovers chamaeoleons as the sister taxon to all remaining acrodontans (including Uromastyx). Also, apart from a Chalarodon + Oplurus clade there are notable differences in the arrangement of the pleurodont iguanians. However, the interrelationships of the pleurodont taxa used here (and the clades they represent) remain problematic even in this larger analysis.

Pyron et al. [2] employ a "supermatrix approach" to include 4161 squamatan taxa with data from 12 genes. The supermatrix has unfortunately a very large amount of missing data, $81 \%$. The study confirms most of the previous topologies, but also finds some new arrangements. The main difference between its results and those of the present study is they recover Serpentes as sister to a clade comprising Iguania + Anguimorpha. However, the support for this grouping is moderate ( $79 \%$ bootstrap support).

\section{Lepidosauria - molecular divergence dating}

For the divergence time between Lepidosauromorpha (Lepidosauria plus stem group) and Archosauromorpha 


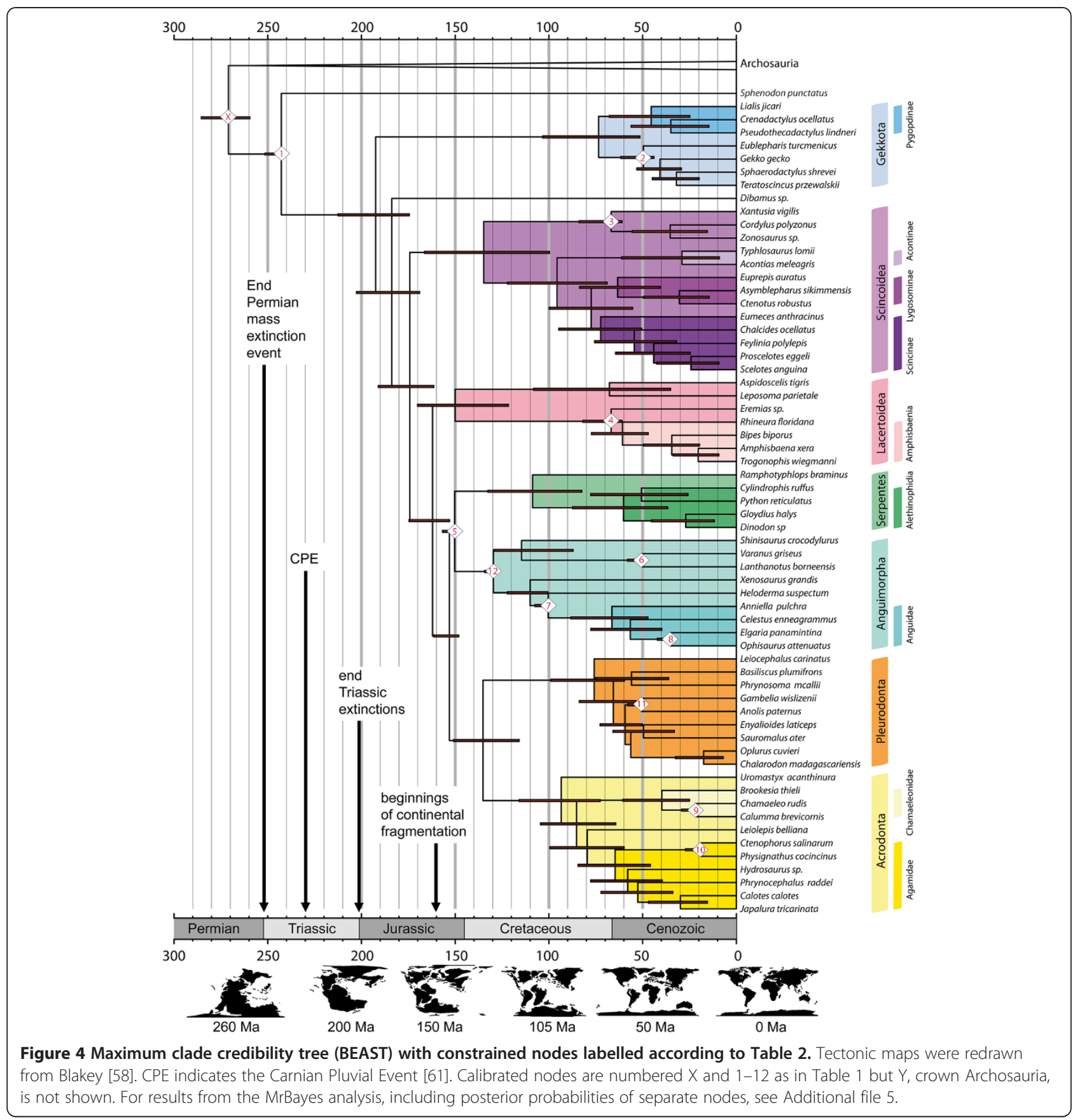

(Archosauria plus their stem group), our analysis provides a median date of 271 Mya (259-285), which is close to the boundary between the Early (Cisurian) and Middle (Guadalupian) Permian. For crown-group Lepidosauria we recover a date of 242 Mya (238-249.5) and for crowngroup Squamata a date of 193 Mya (176-213.2). Dates of origin for all major squamate clades (Gekkota, Scincoidea, Lacertoidea, Serpentes, Anguimorpha, Pleurodonta, and Acrodonta) lie within the Mesozoic (Tables 2 and 3, Figure 4). Only Gekkota and Pleurodonta possess credibility intervals that extend into the Cenozoic. Of these major clades, most have a median estimated date within the Cretaceous except for Lacertoidea which is in the Late Jurassic. Within Iguania, the most recent common ancestor of Acrodonta and Pleurodonta is estimated to have existed in the Early Cretaceous (135 Mya) whereas the clade of Oplurus cuvieri + Chalarodon madagascariensis is estimated to have appeared no more than 33 Mya. The origin of Alethinophidia and Amphisbaenia both lie close to the K-Pg boundary (66 Mya). 


$\begin{aligned} & \text { Table } 3 \text { Dates for the most recent common ancestor of } \\
& \text { major nodes in the lepidosaur phylogenetic tree }\end{aligned}$
\begin{tabular}{lrrr}
\hline Group & Median & 95\% HPD lower & 95\% HPD upper \\
\hline $\begin{array}{l}\text { Crown Lepidosauria } \\
\text { (lizard-tuatara) }\end{array}$ & 242.0 & 238.0 & 249.5 \\
Crown Squamata & 193.0 & 176.0 & 213.2 \\
Crown Gekkota & 76.2 & 52.4 & 101.0 \\
Crown Scincoidea & 137.6 & 107.3 & 168.7 \\
Crown Lacertoidea & 150.0 & 116.4 & 190.7 \\
Crown Serpentes & 109.6 & 81.1 & 137.0 \\
Crown Anguimorpha & 129.5 & 128.1 & 134.2 \\
Crown lguania & 135.8 & 116.7 & 152.0 \\
Crown Pleurodonta & 75.8 & 59.6 & 97.8 \\
Crown Acrodonta & 96.0 & 73.9 & 121.9 \\
\hline
\end{tabular}

These divergence estimates were calculated using the uncorrelated lognormal relaxed clock model in BEAST.

\section{Discussion}

\section{Local palaeoecological implications}

In addition to a recently discovered procolophonid jaw [84], the Vellberg rhynchocephalian material represents the first small vertebrate remains from the source locality. It is generally agreed that Diphydontosaurus-like rhynchocephalians fed on small invertebrates [15,91,138,147-149]. This is supported by their general body size, tooth shape and build of the lower jaw. The teeth are the same shape as tools that can puncture soft materials with relative ease, but are vulnerable to extreme torsion and bending $[138,147]$. The slender jaws provide long out-levers for rapid closure and capture of small active prey but are not suited to withstanding substantial loading forces $[149,150]$. The morphology of the Vellberg rhynchocephalian is consistent with these attributes, which is noteworthy as a predator of small invertebrates has not previously been described from this locality. By contrast, all of the taxa currently known from Vellberg (at least as adults) are suited to feeding on small vertebrates or fish. In turn, the Vellberg rhynchocephalian would itself have been prey for other animals in the community, such as immature individuals of Batrachotomus and other archosauromorphs. Like small vertebrates in modern communities (e.g. [151]), the lepidosaurs were probably an important link in the food chain between primary and tertiary consumers.

\section{Global importance of the locality}

The Middle Triassic record of small gracile vertebrates is poor. There are several rock units from around world that preserve terrestrial vertebrate remains: the Manda beds of Tanzania, Africa (e.g. [152-154]); the oldest part of the Santa Maria Formation (Fm) of Brazil (e.g. [155,156]); the Chañares Fm of Argentina (e.g. [157]); the Moenkopi Fm of North America [158,159]; the Yerrapalli Beds of India (e.g.
$[160,161])$; the upper part of the Beaufort Group of the Karoo Basin (e.g. [162,163]); the Kelamayi Fm, Ermaying Fm, and Hongyanjing Fm of China (e.g. [164,165]); the Donguz and Bukobay of Russia (e.g. [64,166]); the Omingonde Fm of Namibia [167]; part of the Fremouw Fm of Antarctica [168]; the Zarzaïtine Series of Algeria [169]; the Areniscas y Lutitas del Figaro unit of Spain [170]; and a few units in the United Kingdom such as the Otter Sandstone (e.g. [142,143]). However, fossils from the associated localities typically represent medium or large vertebrates such as trematosaurids, rhynchosaurs, cynodonts, and early archosaurs (e.g. [154,160,165]). Animals of small size (skull length $<30 \mathrm{~mm}$ long) such as procolophonid reptiles are occasionally recovered but these are typically robust remains (e.g. $[142,155])$. Therefore, as a new microvertebrate locality, Vellberg is expected to provide a more balanced picture of the Middle Triassic fauna and palaeoecological communities.

Vellberg may also shed light on the early fossil record of important tetrapod groups such as frogs, salamanders, caecilians, albanerpetontids, and choristoderes. All of these groups should have representatives in the Middle Triassic but currently none are known (e.g. [171-178]). Whether this absence of data is related to a failure to sample appropriate facies or a tendency for these animals to be small and gracile, or both, remains unclear [171]. Nevertheless, the material described here demonstrates that Vellberg has the potential to yield remains of other small tetrapods and to provide important information on a poorly known period of significant change in global ecosystems.

\section{Divergence estimates and congruence with the fossil record}

As an independent test of the internal ages of Squamata, we compared them to eight well described and dated fossils that could have been used as additional age constraints. All of them support our dating (Additional file 6), being as old or older than the mean of the estimate. However in three cases they would have truncated the younger bound of the credibility intervals by about 10 Mya.

Beside the manual control of eight alternative calibrations, we also ran the fossil-based cross validation analysis implemented in the penalized likelihood (PL) method of Near and Sanderson [131] on the 14 fossils used (Additional file 6). Simplified, the cross validation procedure sequentially removes one fossil at a time and estimates the node it constrains, to test whether a fossil causes a significant shift towards an older age of the node. Although this is not necessarily a problem with well described fossils, it may indicate a significant rate change close to that node that needs to be calibrated. Cross validation of our data set indicates that the most influential fossil is the calibration of crown-group Diapsida CNY (increased by 52 Mya, fraction score 0.24). This result is not unexpected as it is the node that 
constrains the root of the phylogeny (Additional file 6). The only other fossil that increases the age estimate significantly in the PL analysis is the fossil constraining the crown-group Anguimorpha CN12 (Figure 4), with an increase of $\sim 8.6$ Mya and a fraction score of 0.07 .

\section{Prior distribution of fossil-constrained ages}

The setting of prior distributions for constrained ages is a non-trivial task. For the final dating analysis we used an exponential prior calibration density on divergence times. This approach means that the likelihood for the age of a node is highest at the age of the fossil, whilst the older possible ages have lower likelihood. Statistically the first ancestor of a lineage is not the oldest fossil known or recognisable clade member based on clear autapomorphies [179]. Therefore the use of the exponential prior is suboptimal, and the inferred ages are likely to be more prone to underestimation compared to other alternative priors. The widely used lognormal prior (see e.g. $[39,43]$ ) implies that it is more likely for the real age to be older than the fossil. It can be argued that this prior would better represent the ghost lineage that must exist. However, in most cases there is no objective way of choosing the shape of the prior distribution, especially not in the case of organisms that are rarely preserved as fossils, and the analysis would potentially be highly biased toward the authors' opinion on the fossil ghost range. Even if the lognormal prior could potentially approximate the true ages better, we chose the exponential prior because the minimum age of the fossil constraint is the only known date, the prior will be less biased toward the opinions of the researchers, and it represents a sound method from a philosophical viewpoint; our hypothesis is easily falsified if older fossils are found.

For comparison we also ran the analysis with less informative priors, such as a uniform prior with minimum age from the fossil and maximum age 50 million years older, which is probably too old for at least most of the constrained nodes. This approach tended to push all nodes towards older ages, resulting in median ages close to the given maximum age. It seems unlikely that all fossil records have a "ghost range" of almost 50 million years, so we do not recommend this prior distribution unless there is no other way of constraining the node.

The mean of the exponential prior was set consistently to 4.0 (in absolute ages a possible interval of 15-20 Mya with a small probability of estimated dates being older) to provide a plausible and hopefully useful dating of the lepidosaur and squamate divergence times. As a comparison we ran analyses with mean 5.0 and 6.0 (intervals of about 20 and 25 Mya, respectively). In general the resulting ages were within the range of \pm 5 My compared to the analysis with mean 4 , but in some cases with larger credibility intervals (data not shown).
To check the influence of the highly informative priors on ages and monophyly, we also ran the same analysis but with sampling from priors only (by creating an empty alignment). The topology obtained was different, despite monophyly enforced on 16 nodes (beside the nodes constrained by fossil ages, mammals were set as sister to the reptiles (including Aves), and Squamata was set as monophyletic). The posterior density of ages on constrained nodes was similar for some of the nodes, whilst others had a very different distribution. This indicates that the results were not determined by the prior assumptions alone, but that the sequence data also influenced the results for all nodes.

\section{Previous age estimates of lepidosaurs and squamates}

Previous studies attempting to estimate the timing of the origin of Lepidosauria and Squamata have suggested a range of different ages (Table 1, Figure 5). The "outliers", unusually recent or old dates, may be due to the method used, the number and selection of taxa, choice of molecular marker and of course the choice and number of fossil calibrations.

Gorr et al. [40] used a global clock approach to estimate divergence times within reptiles (including Aves). They concluded that there were large differences in evolutionary rates of reptilian hemoglobins between larger groups, causing an erroneous topology, so their age estimates should be viewed with caution. In a study on vertebrates, Kumar and Hedges [35] estimated gene-specific substitution rates, dated the separate gene trees, and then averaged over the trees to get one dated tree. As rates vary among lineages and therefore do not obey a global clock, they first excluded genes with extensive heterogeneity, and excluded the outliers before averaging over gene trees. Despite this, all nodes closer to the root showed large ghost ranges between estimates and first fossil record (e.g. Agnatha originating in the Precambrian), which is likely due to the method being unable to distinguish between extensive time or fast substitution rates. They conclude that the molecular ages are not overestimating the divergences, and that there are substantial gaps in the fossil record. Their estimate for Lepidosauria was 276 \pm 54.4 Mya.

Janke et al. [48] used mitochondrial genomes of a total 35 species to obtain rough estimates of divergence times for Squamata and turtles, assuming a constant evolutionary rate between 2 reference points: the Synapsida/ Diapsida split (310 Mya) and the Crocodylidae/Aves split (254 Mya). Previously published genomes of a snake and side-necked turtle were excluded on the basis that their fast evolutionary rates complicate the phylogenetic analysis. The phylogeny and dating only contained two squamates (Iguana and the mole skink Eumeces). Neverthless, the origin of "Squamata" is stated to be 


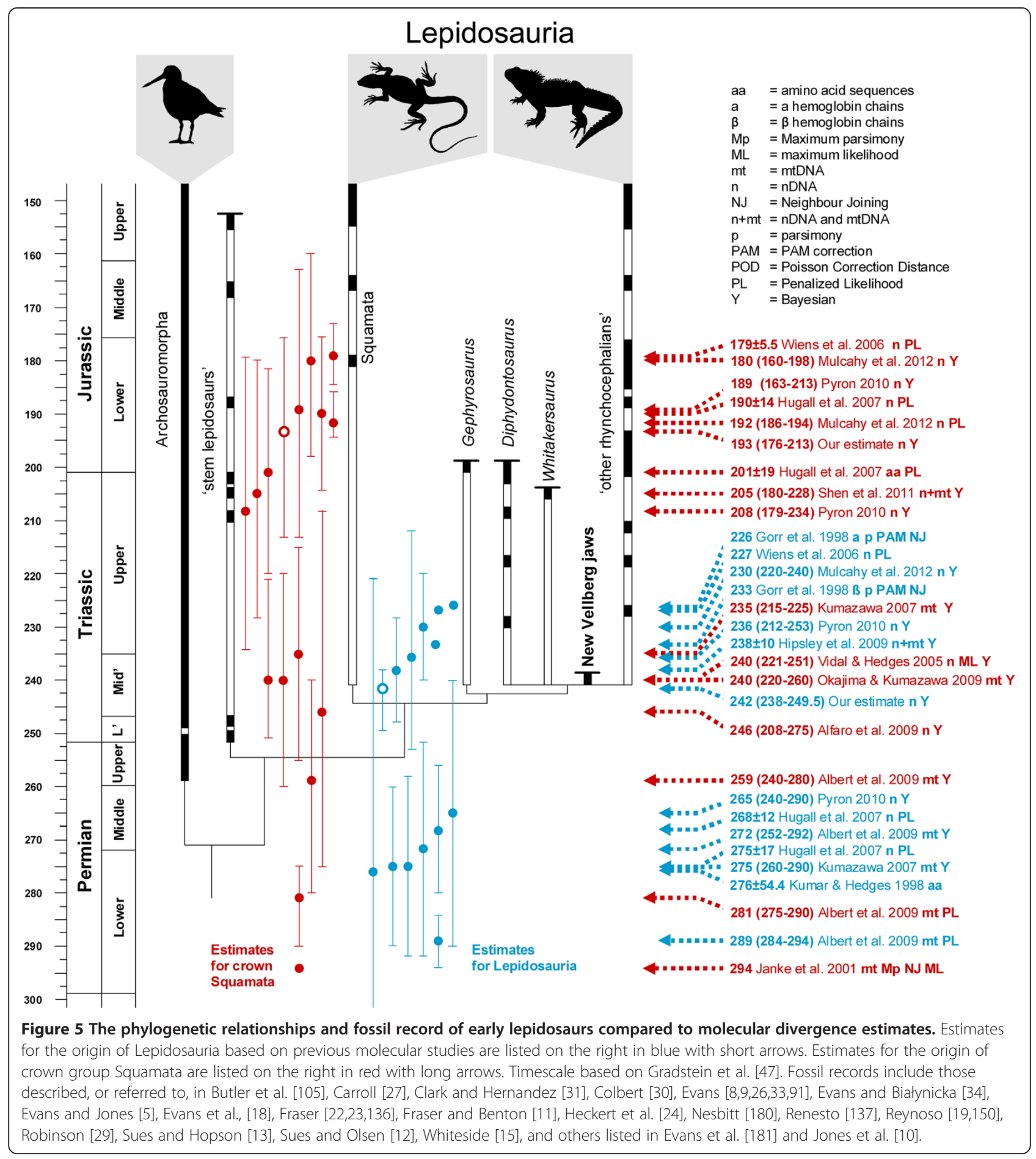

294 $\mathrm{Ma}$ and this date is argued to be consistent with the fossil record. However, this value actually represents the estimated divergence time between the lineage that includes the two squamates from one that includes turtles, crocodiles, and birds (Sphenodon was not used). Therefore this estimate more correctly represents the divergence time of Lepidosauromorpha rather than Squamata.

In general, studies using the Bayesian "multidivtime" method [182] give older age estimates than our study [37,38,49-51]. This is most likely an artifact of the method, which due to a strong autocorrelation 
assumption (the "minab" prior) tends to smooth ages towards the root of the tree to be consistent with the greatest tree depth (e.g. $[36,183])$. This bias is also more prominent in studies with few taxa, and in the studies listed above the number of squamates range between 19 and 38. In practical terms this means that most of the employed minimum age constraints towards the leaves are uninformative in these "multidivtime" analyses. For the age of Lepidosauria we find no overlap between our deepest credibility interval (251.4 Mya) with the shallowest confidence intervals of Kumazawa [37] or Albert et al. [38], and in all the above mentioned studies using multidivtime crown-group Squamata is estimated to be Triassic or older.

Wiens et al. [41] used the semi-parametric penalized likelihood (PL) method of Sanderson [102] and 11 fossil constraints. For the PL analysis it is necessary to set a fixed age close to the root. The focus of the study was the internal divergences in Squamata, and they therefore chose to use the oldest known rhynchocephalian fossil to fix the most recent common ancestor of Squamata and Rhynchocephalia to 227 Mya. This approach may have caused an underestimation of the age of crown-group Squamata (178.7 Mya compared to 193.1 in this study). Hugall et al. [36] used RAG1 sequence and the PL method to study tetrapod diversification, including a total of 35 squamates. They used a maximum age of 450 Mya for the lungfish-tetrapod root and tested different sets of calibrations for internal nodes. All employed constraints were fixed, to avoid the method artefact of "model overfitting", meaning that constraints closer to the leaves can lead to overestimation of deeper nodes. They estimated the split median ages between Sphenodon and Squamata to be 250-275 Mya, and that of crown-group Squamata to be 171-201 Mya, depending on the calibration scheme employed.

Hipsley et al. [42] used the same constraint for the lizard-tuatara split as Wiens et al. [41] but the former used a Bayesian probabilistic method as implemented in the TreeTime software [184]. To account for the uncertainty in fossil calibrations and the likelihood of the true age of a node being older than the first fossil record, the age constraint was set with a hard upper bound of 228 Mya and soft lower bound of 239.4 Mya. Their estimate for the Sphenodon-Squamata split was 238 \pm 10 Mya.

Pyron [39] proposed a method that can objectively test fossil placement and the likelihood of age estimates by comparisons between datasets of different studies. The empirical example is divergence analyses on RAG-1 DNA from 129 gnathostome taxa to compare the affect of two different sets of fossil calibrations. The sample included Sphenodon and 44 squamates. The uncorrelated lognormal method in BEAST was used, and a lognormal distribution was chosen for the prior distribution of ages from the fossil calibrations. Four fossil calibrations from Müller and Reisz [52] provided a mean estimate of 236 Mya (credibility interval 212-253) for Lepidosauria and 189 Mya (163-213) for Squamata whereas five fossil calibrations from Hugall et al. [36] provided a mean estimate of 265 Mya (240-290) for Lepidosauria and 208 Mya (179-234) for Squamata. The shallower estimates were preferred based on a comparison to the wider fossil record. These dates are similar to our own but have greater confidence intervals.

Mulcahy et al. [43] estimated divergence dates for squamates using 64 ingroup species and 25 nuclear loci $(19,020$ base pairs in total), comparing the results obtained from Penalized Likelihood (r8s) and the uncorrelated lognormal method in BEAST. The overlap between their study and the present one is substantial for terminal taxa. There are however some important differences in the fossil constraints such as the use of a younger rhynchocephalian fossil here (for a detailed comparison see Additional file 1). Mulcahy et al. [43] fixed the topology to the same maximum likelihood tree they used as input in the r8s analysis, to facilitate direct comparisons of ages between PL and BEAST, whilst we only constrained the calibrated nodes to be monophyletic. As opposed to our approach of using exponential age priors, Mulcahy et al. [43] applied lognormal distribution of ages for the 11 fossil constrained internal (Lepidosauromorpha) nodes. The oldest rhynchocephalian was set to 222.8 Mya, based on the Vinita specimen from the Ladinian-Carnian boundary. Note that this age was chosen using the timescale of Gradstein et al. [46] rather than the more recent Gradstein et al. [47]. The lognormal priors were set to have a mean and standard deviation of 1.0 - meaning a very narrow interval (about 3 Mya) with an arbitrary mean close to the minimum age of the fossil (e.g. for Lepidosauria 223.4 Mya, 222.9225.9). Mulcahy et al. [43] conclude that the BEAST/ lognormal clock analysis gives younger ages than the $\mathrm{r} 8 \mathrm{~s} / \mathrm{PL}$ analysis. This is not surprising, considering that the internal priors have soft lower bounds but are strong enough to behave as if they have a hard bound, thereby constraining other internal nodes more than the minimum age constraints in the PL analysis, where the only lower bound is the fixed root. This is also likely to be the reason why the BEAST estimates seem more stable with narrower credibility intervals.

\section{Origin time of Lepidosauria, crown-Squamata, and other major clades}

The Vellberg jaw helps to bridge an important gap in the fossil record and establish that Lepidosauria (stem group Rhynchocephalia, and stem group Squamata) 
diverged at least 240 Mya (Figure 4). Discovery of lepidosaur remains in the Middle Triassic is consistent with previous predictions made by palaeontologists (e.g. $[9,26,34])$. It is also consistent with the Late Triassic rhynchocephalian fossil diversity [9,23-25]. This new record from Vellberg supersedes previously used molecular dating calibration points of 223, 227, or 228 Mya for the lizard-tuatara split [37-43,45].

For the divergence between Lepidosauromorpha and Archosauromorpha (bird-lizard split) the median of our estimate, 271 Mya (259-285), lies close to the boundary between the Lower and Middle Permian. This date is deeper than the oldest known fossils of either group (Figure 5): the earliest known archosauromorph is Protorosaurus from the Upper Permian (Wuchiapingian) of northeast England (UK) and the Kupferschiefer of Germany [104] and the earliest certain lepidosauromorph is Sophineta from the Lower Triassic (Olenekian) of Poland [5,34]. However, the possibility that large gaps in the fossil record remain, particularly so for stemlepidosaurs (>20 Mya), highlights the need to survey further fossil localities in the Middle and Late Permian for small vertebrates.

Importantly, our estimate strongly suggests that the origin of Lepidosauria postdates the Permian mass extinction event (252 Mya), which represents a significant period of environmental upheaval possibly linked to a runaway green house environment $[65,67,68]$. An EarlyMiddle Triassic origin and radiation of Lepidosauria would be associated with general changes from fairly uniform warm-arid environments towards ones experiencing humid-arid fluctuations and monsoon systems $[59,61,62,90]$. Complex biodiversity was still in the process of reestablishment after the Permian end mass extinction event $[65,67,68]$. Vegetation in the Middle Triassic was dominated by gymnosperms such as cycads, ginkos and conifers $[59,62]$. Coeveal macrofaunal changes include the diversification of early archosaurs such as the sail-backed poposaurs and appearance of the first dinosauriformes (e.g. [105,152,180,185]). The subsequent "Carnian Pluvial Event" (CPE) of the Late Triassic [61] is thought to represent a global increase in rainfall and further shifts towards more humid climates (Figure 4).

Our results suggests that the origin of crown-group Squamata lies in the Early Jurassic,190 Mya (175-212). We cannot exclude the possibility that crown-squamates appeared before the late Triassic extinctions but our median estimate post-dates them. Our estimate lies soon after changes in general vegetation that indicate changes towards warmer climates and greater continental aridity $[54,62]$. This may be part of a general shift towards more regionalised climates and environments, at least in the northern hemisphere. The earliest secure lizard fossils currently referred to crown-Squamata are
Middle Jurassic in age and therefore do not conflict with our estimate $[8,17,18]$.

The Cretaceous origin of most major crown-groups suggests the radiation of Squamata occurred after and alongside continental fragmentation (Figure 4, Table 3, $[58,186]$. Therefore the widespread distribution of many modern lizard groups today (e.g. [1]) probably requires a number of post Jurassic dispersal events to have occurred. Evidence that transoceanic dispersal of squamates is possible does certainly exist (e.g. [187-190]) and the distances between continental fragments in the second half of the Mesozoic were much less than they are today [191].

Our estimates for the origin of most modern groups coincide with a general improvement of the squamate fossil record [5-8] and contraction of rhynchocephalian distributions to southern continents $[10,20,181,192]$. This shift in lepidosaur communities may be related to expansion/ contraction of preferred environments $[6,7,21]$ or displacement by active competition [20,192,193], but distinguishing between the two hypotheses remains problematic [5,25]. The Early Jurassic to Early Cretaceous diversification of crown-group squamates is concurrent with that of several modern lineages of beetles $[54,56]$. However, rather than reflecting a predator-prey relationship it may be symptomatic of the general development of more modern ground cover and microhabitats.

The divergence estimates for both crown-group Iguania, 136 Mya (117-152), and total group Iguania 153 Mya (148-161) post date the fossil taxon Bharatagama from India originally referred to Iguania [18]. It is possible that Bharatagama represents an early stem crown-group squamate with a jaw morphology convergent with modern acrodont iguanians, or that it belongs to another clade.

Our estimated origin time for Gekkota, 76 Mya (52-101), is younger than that of some previous studies but there is some overlap between credibility intervals (e.g. $[36,43,194])$. There are also two early-mid Cretaceous fossils that could potentially challenge our crown-group age of Gekkota: Cretaceogekko burmae preserved in amber from Myanmar (>97.5 Mya) [195] and Hoburogekko suchanovi from Mongolia (125-99.6 Mya) $[196,197]$. Both fossils likely belong to the gekkotan lineage but their precise relationship with extant geckos is unclear [197]. Cretaceogekko was described as crowngroup gekkotan based on it's advanced adhesive toe pads, but it has recently been inferred that specialized toe pad morphology has evolved (and been lost) several times across the gekkotan phylogeny [198]. Hence it is not possible from morphological characters alone to determine crown-group affinity. The redescription by Daza et al. [197] of Hoburogekko concludes that the 
combination of jaw and skull characters is likely to belong to a stem-group gekkotan, and that a phylogenetically conservative placement of these Cretaceous fossils is recommended.

\section{Conclusions}

Using the age of a new lepidosaur fossil from the Middle Triassic of Germany and 13 other fossil constraints, we estimate that Lepidosauria originated between 238 and 249.5 Mya (median age 242) in the Early-Middle Triassic, and importantly that their origin and diversification occurred after the end-Permian mass extinction rather than before it. This date is consistent with previous estimates inferred using fossil data such as that made by SE Evans ([26]: page 407). We also estimate crowngroup Squamata originated between 175 and 212 Mya (median age 193) in the Late Triassic-Early Jurassic concurrently with notable shifts in vegetation, fauna, and climate. However, the precise relationship between the appearance of crown-group squamates and the end Triassic mass extinction remains uncertain. The origins of most major squamate clades such as Anguimorpha and Acrodonta occurred in the Late Jurassic and Cretaceous, taking place during and after continental fragmentation. Therefore, oceanic dispersal is likely to have been an important factor in the global radiation and evolution of squamates.

Molecular datings are an important part of evolutionary biology, and thousands of studies including dated phylogenies have been published in the last few decades. Several studies have shown that an increased number of taxa and, more importantly, correctly assigned fossil constraints improve datings. There is however no consensus about which methods provide the most reliable results, and for the Bayesian methods the priors on node ages (as well as priors affecting e.g. topology) are highly debated. All molecular datings are open for refinement, and the estimates given here for the origin of Lepidosauria and Squamata will probably be superseded. As the only extant rhynchocephalian, Sphenodon represents the best available sister taxon for molecular analysis. Nevertheless, it is taxonomically isolated: the end member of a very long branch. Large credibility intervals will persist around the divergence date of crown-group Squamata in the absence of fossils that can be reliably placed around this node. Until then, the new lepidosaur fossil described in this study will play an important part in future divergence estimate analyses in early lepidosaur history.

\section{Note added post-acceptance}

Renesto \& Bernardi [199] recently re-attributed Megachirella to Lepidosauromorpha on the basis of a new phylogenetic analysis.

\section{Availability of supporting data}

The matrix is also deposited in the Dryad data repository (http://datadryad.org/), with the Digital Object Identifier (DOI) of http://dx.doi.org/10.5061/dryad.gr573.

\section{Additional files}

\section{Additional file 1: Summary of previous molecular divergence estimates, further details of the morphological phylogenetic analysis, and calibration points employed.}

Additional file 2: A movie of a surface model of SMNS 91060 based on CT data.

Additional file 3: A movie of a surface model of SMNS 91061 based on CT data.

Additional file 4: List of sequences used from GenBank for 77 extant amniote taxa.

Additional file 5: Majority rule consensus tree from MrBayes, phylogram with posterior probabilities shown.

Additional file 6: Results of the fossil cross-validation using r8s (see [131]).

\section{Competing interests}

The authors declare we have no competing interests.

\section{Authors' contributions}

$\mathrm{MEHJ}$ carried out the morphological comparisons, $C T$ data processing, Scanning Electron Microscopy, camera lucida drawings, initial calibration point evaluation, drafted the manuscript, and contributed to the morphological phylogenetic analysis. $\mathrm{CAH}$ collected the genetic sequence data and performed the sequence alignment. CLA carried out the molecular dating analyses and final morphological phylogenetic analysis. SEE contributed to morphological comparisons, initial identification of calibration points, and the morphological phylogenetic analysis. JM evaluated calibration points. RRS carried out the field work and prepared the specimens. MEHJ and CLA wrote the paper. All authors reviewed, edited, and approved the final manuscript.

\section{Acknowledgements}

We are grateful to Ute Günter and Traugott Haubold for donating the material to the SMNS, and to the owner of the quarry, Manfred Schumann, for providing us unlimited access to his property and for helping in many technical ways to secure so many fossils. We also thank Ryoko Matsumoto (UCL) for close-up photography of SMS 91061; Jerry Hooker (The Natural History Museum, UK), Mark Hutchinson (South Australia Museum), and Lance Grande (The Field Museum, Chicago, USA) for correspondence; Richard Butler (Ludwig-Maximilians-Universität München, Germany) and Anjali Goswami (UCL) for discussion; Pamela G. Gill, Elizabeth J. Loeffler, Remmert Schouten (all The University of Bristol, UK), Ray J. Symonds (University Museum of Zoology, Cambridge, UK), Luis Chiappe (The Natural History Museum Los Angeles County, USA), John Foster (Museum of Western Colorado, USA), Ken Carpenter (The Denver Museum of Nature and Science, USA), Sandra D. Chapman and David J. Gower (The Natural History Museum, London), and Mark Carnall (The Grant Museum of Zoology and Comparative Anatomy, UCL, UK) for access to comparative material; Mark Turmaine (UCL) for access to a Scanning Electron Microscope; Neil Curtis and Sue Taft (The University of Hull) for facilitating initial CT scanning; Kyle Armstrong and Oliver Wooley (The University of Adelaide) for use of their laptops at critical points in time; and Diego San Mauro and one anonymous reviewer for valuable comments that helped improve the manuscript. It should be noted that parts of the analyses carried out by CLA were done using the Albiorix cluster at the Department of Biology and Environmental Sciences, Gothenburg University. Also although now based at The University of Adelaide the lead author MEHJ was based at UCL for the entirety of this research.

\section{Author details}

${ }^{1}$ Research Department of Cell and Developmental Biology, Anatomy Building, UCL, University College London, Gower Street, London WCIE 6BT, 
UK. ${ }^{2}$ School of Earth and Environmental Sciences, The University of Adelaide, North Terrace, Adelaide, South Australia 5005, Australia. ${ }^{3}$ University of Gothenburg, Department of Plant and Environmental Sciences, Gothenburg, Sweden. ${ }^{4}$ Museum für Naturkunde - Leibniz-Institut für Evolutions- und Biodiversitätsforschung an der Humboldt-Universität zu Berlin, Berlin, Germany. ${ }^{5}$ Staatliches Museum für Naturkunde, Rosenstein 1, D-70191, Stuttgart, Germany. ${ }^{6}$ Berlin-Brandenburg Institute of Advanced Biodiversity Research (BBIB), 14195 Berlin, Germany.

\section{Received: 5 April 2013 Accepted: 2 September 2013}

Published: 25 September 2013

\section{References}

1. Zug GR, Vitt $L$, Caldwell JP: Herpetology, an introductory biology of amphibians and reptiles. New York: Academic Press; 2001

2. Pyron RA, Burbrink FT, Wiens JJ: A phylogeny and revised classification of Squamata, including 4161 species of lizards and snakes. BMC Evol Biol 2013, 13:93.

3. Alfaro ME, Santinia F, Brock C, Alamillo H, Dornburg A, Rabosky DL, Carnevale G, Harmon L: Nine exceptional radiations plus high turnover explain species diversity in jawed vertebrates. Proc Nat Acad Sci 2009, 106:13410-13414

4. Jones MEH, Cree A: Tuatara. Curr Biol 2012, 22:986-987.

5. Evans SE, Jones MEH: The origin, early history and diversification of lepidosauromorph reptiles. In New Aspects of Mesozoic Biodiversity, Lec Not Earth Sci. 132nd volume. Edited by Bandyopadhyay S. 2010:27-44.

6. Evans SE: Lizards: evolution, early radiation and biogeography. In Sixth Symposium on Mesozoic Terrestrial Ecosystems and Biota Short Papers. Edited by Sun A, Wang Y. Beijing: China Ocean Press; 1995:271-283.

7. Evans SE: Lepidosaurian faunas from the Early Cretaceous: a clade in transition. In Lower and Middle Cretaceous Continental Ecosystems, Bull New Mex Mus Nat Hist Sci. 14th edition. Edited by Lucas SG, Kirkland Jl, Estep JW. Albuquerque: New Mexico Museum of Natural History and Science; 1998:195-200.

8. Evans SE: Crown group lizards from the Middle Jurassic of Britain Palaeontographica A 1998, 250:123-154.

9. Evans SE: At the feet of the dinosaurs: the origin, evolution and early diversification of squamate reptiles (Lepidosauria: Diapsida). Biol Rev 2003, 78:513-551.

10. Jones MEH, Tennyson AJD, Worthy JP, Evans SE, Worthy TH: A sphenodontine (Rhynchocephalia) from the Miocene of New Zealand and palaeobiogeography of the tuatara (Sphenodon). Proc Roy Soc B 2009, 276:1385-1390.

11. Fraser NC, Benton MJ: The Triassic reptiles Brachyrhinodon and Polysphenodon and the relationships of the sphenodontids. Zool I Linn Soc 1989, 96:413-445.

12. Sues H-D, Olsen PE: Triassic vertebrates of Gondwanan aspect from the Richmond Basin of Virginia. Science 1990, 249:1020-1023.

13. Sues H-D, Hopson JA: Anatomy and phylogenetic relationships of Boreogomphodon jeffersoni (Cynodontia: Gomphodontia) from the Upper Triassic of Virginia. J Vertebr Paleontol 2010, 30:1202-1220.

14. Sues H-D, Olsen PE, Kroehler PA: Small tetrapods from the Upper Triassic of the Richmond basin (Newark Supergroup), Virginia. In In the shadow of the dinosaurs: Early Mesozoic tetrapods. Edited by Fraser NC, Sues H-D. Cambridge: Cambridge University Press; 1994:161-170.

15. Whiteside DI: The head skeleton of the Rhaetian sphenodontid Diphydontosaurus avonis gen. et sp. nov., and the modernising of a living fossil. Phil Trans R Soc B 1986, 312:379-430.

16. Datta PM, Ray S: Earliest lizard from the Late Triassic (Carnian) of India. J Verteb Paleontol 2006, 26:795-800

17. Hutchinson MN, Skinner A, Lee MSY: Tikiguania and the antiquitiy of squamate reptiles (lizards and snakes). Biol Lett. in press 10.1098/ rsbl.2011.1216

18. Evans SE, Prasad GVR, Manhas BK: Fossil lizards from the Jurassic Kota formation of India. J Vertebr Paleontol 2002, 22:299-312.

19. Reynoso VH: A Middle Jurassic Sphenodon-like sphenodontian (Diapsida: Lepidosauria) from Huizachal Canyon, Tamaulipas, Mexico. J Vertebr Paleontol 1996, 16:210-221.

20. Apesteguía S, Novas FE: Large Cretaceous sphenodontian from Patagonia provides insights into lepidosaur evolution in Gondwana. Nature 2003, 425:609-612.
21. Rauhut OWM, Heyng AM, López-Arbarello A, Hecker A: A new rhynchocephalian from the Late Jurassic of Germany with a dentition that is unique amongst tetrapods. PLOS ONE 2012, 10:e46839.

22. Fraser NC: A new rhynchocephalian from the British Upper Trias. Palaeontol 1982, 25:709-725.

23. Fraser NC: New Triassic sphenodontids from South West England and a review of their classification. Palaeontol 1986, 29:165-186.

24. Heckert AB, Lucas SG, Rinehart LF, Hunt AP: A new genus and species of sphenodontian from the Ghost Ranch Coelophysis Quarry (Upper Triassic: Apachean), Rock Point Formation, New Mexico, USA. Palaeontol 2008, 51:827-845.

25. Meloro $\mathrm{C}$, Jones MEH: Tooth and cranial disparity in the fossil relatives of Sphenodon (Rhynchocephalia) dispute the persistent 'living fossil' label. J Evol Biol 2012, 11:2194-2209.

26. Evans SE: A new lizard-like reptile (Diapsida: Lepidosauromorpha) from the Middle Jurassic of Oxfordshire. Zool J Linn Soc 1991, 103:391-412.

27. Carroll RL: Permo-Triassic 'lizards' from the Karroo. Palaeontol Afr 1975, 18:71-87.

28. Waldman M, Evans SE: Lepidosauromorph reptiles from the Middle Jurassic of Skye. Zool J Linn Soc 1994, 112:135-150.

29. Robinson PL: Gliding lizards from the Upper Keuper of Great Britain. Proc Geol Soc 1962, 1601:137-146.

30. Colbert EH: Icarosaurus - a gliding reptile from the Triassic of New Jersey. Am Mus Nov 1966, 2246:1-23.

31. Clark JM, Hernandez RR: A new burrowing diapsid from the Jurassic La Boca Formation of Tamaulipas, Mexico. J Vertebr Paleontol 1994, 14:180-195.

32. Renesto S, Posenato R: A new lepidosauromorph reptile from the Middle Triassic of the Dolomites (Northern Italy). Riv Ital Paleont Strat 2003, 109:463-474.

33. Evans SE: An early kuehneosaurid reptile (Reptilia: Diapsida) from the Early Triassic of Poland. Palaeontol Pol 2009, 65:145-178.

34. Evans SE, Borsuk-Białynicka M: A small lepidosauromorph reptile from the Early Triassic of Poland. Palaeontol Pol 2009, 65:179-202.

35. Kumar S, Hedges SB: A molecular timescale for vertebrate evolution. Nature 1998, 392:917-920.

36. Hugall AF, Foster R, Lee MS: Calibration choice, rate smoothing, and the pattern of tetrapod diversification according to the long nuclear gene RAG-1. Syst Biol 2007, 56:543-563.

37. Kumazawa Y: Mitochondrial genomes from major lizard families suggest their phylogenetic relationships and ancient radiations. Gene 2007, 388:19-26.

38. Albert EM, San Mauro D, García-París M, Rüber L, Zardoya R: Effect of taxon sampling on recovering the phylogeny of squamate reptiles based on complete mitochondrial genome and nuclear gene sequence data. Gene 2009, 441:12-21.

39. Pyron RA: A likelyhood method for assessing molecular divergence time estimates and the placement of fossil calibrations. Syst Biol 2010, 59:185-194

40. Gorr TA, Mable BK, Kleinschmidt T: Phylogenetic analysis of reptilian hemoglobins: tree, rates, and divergences. J Mol Evol 1998, 47:471-485.

41. Wiens JJ, Brandley MC, Reeder TW: Why does a trait evolve multiple times within a clade? Repeated evolution of snakelike body form in squamate reptiles. Evolution 2006, 60:123-141.

42. Hipsley CA, Himmelmann L, Metzler D, Müller J: Integration of Bayesian molecular clock methods and fossil-based soft bounds reveals early Cenozoic origin of African lacertid lizards. BMC Evol Biol 2009, 9:151.

43. Mulcahy DG, Noonan BP, Moss T, Townsend TM, Reeder TW, Sites JW, Wiens $\mathrm{J}$ : Estimating divergence dates and evaluating dating methods using phylogenomic and mitochondrial data in squamate reptiles. Mol Phylogenet Evol 2012, 65:974-991.

44. Benton MJ, Donoghue PCJ: Paleontological evidence to date the tree of life. Mol Biol Evol 2007, 24:26-53.

45. Benton MJ: Phylogeny of the major tetrapod groups: morphological data and divergence dates. J Mol Evol 1990, 30:409-424.

46. Gradstein F, Ogg J, Smith A: A geologic time scale 2004. Cambridge UK: Cambridge University Press; 2004.

47. Gradstein FM, Ogg JG, Schmitz M, Ogg G: The geological time scale 2012 Amsterdam: Elsevier; 2012. 
48. Janke A, Erpenbeck D, Nilsson M, Arnason U: The mitochondrial genomes of the iguana (Iguana iguana) and the caiman (Caiman crocodylus): implications for amniote phylogeny. Proc R Soc Lond B 2001, 268:623-631.

49. Okajima $Y$, Kumazawa Y: Mitogenomic perspectives into iguanid phylogeny and biogeography: Gondwanan vicariance for the origin of Madagascan oplurines. Gene 2009, 441:28-35.

50. Shen X-X, Liang D, Wen J-Z, Zhang P: Multiple genome alignments facilitate development of NPCL markers: a case study of tetrapod phylogeny focusing on the position of turtles. Mol Biol Evol 2011, 28:3237-3252

51. Vidal N, Hedges SB: The phylogeny of squamate reptiles (lizards, snakes, and amphisbaenians) inferred from nine nuclear protein-coding genes. C R Biol 2005, 328:1000-1008.

52. Müller J, Reisz R: Four well-constrained calibration points from the vertebrate fossil record for molecular clock estimates. Bioessays 2005, 27:1069-1075

53. Okajima Y, Kumazawa Y: Mitochondrial genomes of acrodont lizards: timing of gene rearrangements and phylogenetic and biogeographic implications. BMC Evol Biol 2010, 10:141

54. Grimaldi D, Engel MS: Evolution of the Insects. Cambridge: Cambridge University Press; 2005.

55. Sellwood BW, Valdes PJ: Mesozoic climates: General circulation models and the rock record. Sediment Geol 2006, 190:269-287.

56. Hunt T, Bergsten J, Levkanicova Z, Papadopoulou A, St. John O, Wild R, Hammond PM, Ahrens D, Balke M, Caterino MS, Gómez-Zurita J, Ribera I, Barraclough TG, Bocakova M, Bocak L, Vogler AP: A comprehensive phylogeny of beetles reveals the evolutionary origins of a superradiation. Science 2007, 318:1913-1916.

57. McElwain JC, Punyasena SW: Mass extinction events and the plant fossil record. TRENDS Ecol Evol 2007, 22:548-557.

58. Blakey RC: Gondwana palaeogeography from assembly to break up - a 500 m.y. odyssey. In Resolving the Late Paleozoic Ice Age in Time and Space, Geol Soc Am Sp Pap. 441st edition. Edited by Fielding CR, Frank TD, Isbell JL.; 2008:1-28.

59. Krassilov V, Karasev E: Paleofloristic evidence of climate change near and beyond the Permian-Triassic boundary. Palaeogeog Palaeoclim Palaeoecol 2009, 284:326-336.

60. Irmis RB: Evaluating hypotheses for the early diversification of dinosaurs. Earth Eviron Sci Trans R Soc Edinburgh 2010, 101:397-426.

61. Preto N, Kustatscher E, Wignall PB: Triassic climates - State of the art and perspectives. Palaeogeog Palaeoclim Palaeoecol 2010, 290:1-10.

62. Bonis NR, Kürschner WM: Vegetation history, diversity patterns, and climate change across the Triassic/Jurassic boundary. Paleobiology 2012, 38:240-264.

63. Olsen PE, Kent DV, Sues H-D, Koeberl C, Huber H, Montanari A, Rainforth EC, Fowell SJ, Szajna MJ, Hartline BW: Ascent of dinosaurs linked to an iridium anomaly at the Triassic-Jurassic boundary. Science 2002, 296:1305-1307.

64. Benton MJ, Tverdokhlebov VP, Surkov MV: Ecosystem remodelling among vertebrates at the Permian-Triassic boundary in Russia. Nature 2004, 432:97-100

65. Kiehl JT, Shields CA: Climate simulation of the latest Permian: Implications for mass extinction. Geology 2005, 33:757-760

66. Whiteside JH, Olsen PE, Eglinton T, Brookfield ME, Sambrotto RN Compound-specific carbon isotopes from Earth's largest flood basalt eruptions directly linked to the end-Triassic mass extinction. Proc Nat Acad Sci 2010, 107:6721-6725.

67. Irmis RB, Whiteside JH: Delayed recovery of non-marine tetrapods after the end-Permian mass extinction tracks global carbon cycle. Proc $R$ Soc Lond B 2011, 279:1310-1318

68. Chen Z-Q, Benton MJ: The timing and pattern of biotic recovery following the end-Permian mass extinction. Nat Geosci 2012, 5:375-383.

69. Britton T: Estimating divergence times in phylogenetic trees without a molecular clock. Syst Biol 2005, 54:500-507.

70. Bremer K, Friis EM, Bremer B: Molecular phylogenetic dating of asterid flowering plants shows early Cretaceous diversification. Syst Biol 2004, 53:496-505.

71. Rutschmann F, Eriksson T, Abu Salim K, Conti E: Assessing calibration uncertainty in molecular dating: the assignment of fossils to alternative calibration points. Syst Biol 2007, 56:591-608.

72. Vitt LJ, Pianka ER: Deep history impacts present-day ecology and biodiversity. Proc Nat Acad Sci 2005, 22:7877-7881.
73. Macey JR, Schulte JA II, Larson A, Ananjeva NB, Wang Y, Pethiyagoda R, Rastegar-Pouyani N, Theodore J: Evaluating trans-Tethys migration: an example using acrodont lizard phylogenetics. Syst Biol 2000, 49:233-256

74. Parham JF, Parham JF, Donoghue PCJ, Bell CJ, Calway TD, Head JJ, Holroyd PA, Inoue JG, Irmis RB, Joyce WG, Ksepka DT, Patané JSL, Smith ND, Tarver JE, Tuinen MV, Yang Z, Angielczyk KD, Greenwood JM, Hipsley CA, Jacobs L, Makovicky PJ, Müller J, Smith KT, Theodor JM, Warnock RCM, Benton MJ: Best practices for justifying fossil calibrations. Syst Biol 2012, 61:346-359.

75. Schoch RR: Stratigraphie und Taphonomie wirbeltierreicher Schichten im Unterkeuper (Mitteltrias) von Vellberg (SW-Deutschland). Stuttgarter Beitr Naturkd B 2002, 318:1-30

76. Menning M, Gast R, Hagdorn H, Kading KC, Simon T, Szurlies M, Nitsch E: Time scale for the Permian and Triassic groups in the Stratigraphical Scale of Germany 2002, cyclostratigraphic calibration of the Dyassic and Germanic Triassic groups and the age of the strata Roadium to Rhaetium 2005. News Strat 2005, 41:173-210.

77. DSK: Deutsche Stratigraphische Kommission (Hrsg.): Stratigraphie von Deutschland IV - Keuper. Courier Forschungsinstitut Senckenberg 2005, 253:296. S., 64 Abb., 50 Tab., 2 Taf.; Frankfurt am Main.

78. Kozur HW, Bachman GH: Updated correlation of the Germanic Triassic with the Tethyan scale and assigned numeric ages. Berichte Geol 2008, 76:53-58.

79. Wild R: The fossil deposits of Kupferzell, Southwest Germany. Mesoz Vertebr Life 1980, 1:15-18.

80. Gower DJ: The cranial and mandibular osteology of a new rauisuchian archosaur from the Middle Triassic of southern Germany. Stuttgarter Beitr Naturkd B 1999, 280:1-49.

81. Schoch RR: Comparative osteology of Mastodonsaurus giganteus (Jaeger, 1828) from the Middle Triassic (Lettenkeuper: Longobardian) of Germany (Baden-Württemberg, Bayern, Thüringen). Stuttgarter Beitr Naturkd B 1999, 278:1-175.

82. Schoch RR: A complete trematosaur amphibian from the Middle Triassic of Germany. J Vert Paleont 2006, 26:29-43.

83. Schoch RR: A new stereospondyl from the German Middle Triassic, and the origin of the Metoposauridae. Zool J Linn Soc 2008, 152:79-113.

84. Schoch RR: A procolophonid-like tetrapod from the German Middle Triassic. N Jb Geol Paläont Abh 2011, 259:251-255.

85. Hopson JA, Sues H-D: A traversodont cynodont from the Middle Triassic (Ladinian) of Baden-Württemberg (Germany). Palaeontol Zeit 2006, 80:124-129.

86. Witzmann F, Schoch RR, Maisch MW: A relic basal tetrapod from Germany: first evidence of a Triassic chroniosuchian outside Germany. Naturwissenschaften 2008, 95:67-72.

87. Gower DJ, Schoch RR: Postcranial anatomy of the rauisuchian archosaur Batrachotomus kupferzellensis. J Vertebr Paleontol 2009, 29:103-122.

88. Schoch RR, Witzmann F: Cranial morphology of the plagiosaurid Gerrothorax pulcherrimus as an extreme example of evolutionary stasis. Lethaia 2012, 45:371-385.

89. Lindström S, Vosgerau H, Piasecki S, Henrik Nielsen L, Dybkjær K, Erlström M: Ladinian palynofloras in the Norwegian-Danish Basin: a regional marker reflecting a climate change. Geol Sur Denmark Greenl Bull 2009, 17:21-24.

90. Stefani M, Furin S, Gianolla P: The changing climate framework and depositional dynamics of Triassic carbonate platforms from the Dolomites. Palaeogeog Palaeoclim Palaeoecol 2010, 290:43-57.

91. Evans SE: The skull of a new eosuchian reptile from the Lower Jurassic of South Wales. Zool I Linn Soc 1980, 70:203-264.

92. Evans SE: The early history and relationships of the Diapsida. In The Phylogeny and Classification of the Tetrapods. Edited by Benton MJ. Oxford, UK: Oxford University Press; 1988:221-253

93. Benton MJ: Classification and phylogeny of the diapsid reptiles. Zool J Linn Soc 1985, 84:97-164

94. Gauthier JA, Estes R, de Queiroz K: A phylogenetic analysis of the Lepidosauromorpha. In Phylogenetic relationships of the lizard families: essays commemorating Charles L. Camp. Edited by Estes R, Pregill G. Stanford, CA, USA: Stanford University Press; 1988:15-98.

95. Swofford DL: PAUP*: phylogenetic analysis using parsimony, version $4 b 10$ Sunderland, MA, USA: Sinauer Associates; 2003

96. Ronquist F, Huelsenbeck JP: MrBayes 3: Bayesian phylogenetic inference under mixed models. Bioinformatics 2003, 19:1572-1574. 
97. Gouy M, Guindon S, Gacuel O: SeaView version 4: a multiplatform graphical user interface for sequence alignment and phylogenetic tree building. Mol Biol Evol 2010, 27:221-224

98. Nylander JAA: MrModeltest V2. Program distributed by the author: Evolutionary Biology Centre, Uppsala University; 2004

99. Ren F, Tanaka H, Yang Z: An empirical examination of the utility of codon-substitution models in phylogeny reconstruction. Syst Biol 2005, 54:808-818.

100. Wahlberg N, West Wheat C: Genomic outposts serve the phylogenomic pioneers: designing novel nuclear markers for genomic DNA extractions of lepidoptera. Syst Biol 2008, 57(2):231-242.

101. Drummond AJ, Rambaut A: BEAST: Bayesian evolutionary analysis by sampling trees. BMC Evol Biol 2007, 7:214

102. Sanderson MJ: Estimating absolute rates of molecular evolution and divergence times: a penalized likelihood approach. Mol Biol Evol 2002, 19:101-109.

103. Drummond AJ, Ho SYW, Phillips MJ, Rambaut A: Relaxed phylogenetics and dating with confidence. PLOS Biol 2006, 4(5):e88.

104. Evans SE, King MS: A new specimen of Protorosaurus (Reptilia: Diapsida) from the Marl Slate (late Permian) of Britain. Yorkshire Geol Soc 1993, 49:229-234.

105. Butler RJ, Brusatte SL, Reich M, Nesbitt SJ, Schoch RR, Hornung JJ: The sailbacked reptile Ctenosauriscus from the Latest Early Triassic of Germany and the timing and biogeography of the early archosaur radiation. PLOS ONE 2011, 6(10):e25693.

106. Bauer AM, Bohme W, Weitschat W: An Early Eocene gecko from Baltic amber and its implications for the evolution of gecko adhesion. $J$ Zool 2005, 265:327-332

107. Wolfe AP, Tappert R, Muehlenbachs K, Boudreau M, McKellar RC, Basinger JF, Garrett A: A new proposal concerning the botanical origin of Baltic amber. Proc R Soc B 2009, 276:3403-3412.

108. Sullivan RM: Caudata and Squamata from Gidley and Silberling Quarries, Montana. J Vertebr Paleontol 1991, 11:293-301.

109. Lofgren DL, Lillegraven JA, Clemens WA, Gingerich PD, Williamson TE: Paleocene biochronology of North America: the Puercan through Clarkforkian land mammal ages. In Late Cretaceous and Cenozoic mammals of North America: biostratigraphy and geochronology. Edited by Woodburne MO. New York: Columbia University Press; 2004:43-105.

110. Lofgren DL, Scherer BE, Clark CK, Standhardt B: First record of Stygimys (Mammalia, Multituberculata, Eucosmodontidae) from the Paleocene (Puercan) part of the North Horn Formation, Utah, and a review of the genus. J Mamm Evol 2005, 12:77-97.

111. Sullivan RM: A New Middle Paleocene (Torrejonian) rhineurid amphisbaenian, Plesiorhineura tsentasi new genus, new species, from the San Juan Basin, New Mexico. J Palaeontol 1985, 59:1481-1485.

112. Prothero DR, Estes R: Late Jurassic lizards from Como Bluff Wyoming and their paleobiogeographic significance. Nature 1981, 286:484-486.

113. Evans SE, Chure DJ: Upper Jurassic lizards from the Morrison Formation of Dinosaur National Mounment. In Vertebrate Paleontology in Utah. Edited by Gillete DD. Utah: Miscellaneous Publication 99-1 Utah Geological Survey; 1999:151-159.

114. Conrad JL, Ast JC, Montanari S, Norell MA: A combined evidence phylogenetic analysis of Anguimorpha (Reptilia: Squamata). Cladistics 2011, 27:230-277.

115. Rieppel O, Grande L: The anatomy of the fossil varanid lizard Saniwa ensidens Leidy, 1870, based on a newly discovered complete skeleton. J Paleontol 2007, 81:643-665.

116. Smith ME, Carroll AR, Singer BS: Synoptic reconstruction of a major ancient lake system: Eocene Green River Formation, Western United States. GSA Bull 2008, 120:54-84.

117. Smith ME, Chamberlain KR, Singer BS, Carroll AR: Eocene clocks agree: coeval 40Ar/ 39Ar, U-Pb, and astronomical ages from the Green Rive Formation. Geol 2010, 38:527-530.

118. Cifelli RL, Kirkland II, Weil A, Deino AL, Kowallis BJ: High precision 40Ar/ 39Ar geochronology of North America's Late Cretaceous terrestrial fauna. PNAS 1997, 94:11163-11167.

119. Nydam RL: A new taxon of helodermatid-like lizard from the AlbianCenomanian of Utah. J Vertebr Paleontol 2000, 20:285-294.

120. Klembara J, Green B: Anguimorph lizards (Squamata, Anguimorpha) from the Middle and Late Eocene of the Hampshire Basin of southern England. J Syst Palaeontol 2010, 8:97-129.
121. Hooker JJ, Grimes ST, Mattey DP, Collinson ME, Sheldon ND: Refined correlation of the UK Late Eocene-Early Oligocene Solent Group and timing of its climate history. Geol Soc Am Sp Pap 2009, 452:179-195.

122. Čerňanský A: A revision of chamaeleonids from the Lower Miocene of the Czech Republic with description of a new species of Chamaeleo (Squamata, Chamaeleonidae). Geobios 2010, 43:605-613.

123. Steininger FF, Wessely G: From the Tethyan Ocean to the Paratethys Sea: Oligocene to Neogene stratigraphy, paleogeography and paleobiogeography of the circum-Mediterranean region and the Oligocene to Neogene Basin evolution in Austria. Mitt Osterr Geol Ges 2000, 92:95-116.

124. Covacevich J, Couper P, Molnar RE, Witten G, Young W: Miocene dragons from Riversleigh: new data on the history of the family Agamidae (Reptilia: Squamata) in Australia. Mem Queensland Mus 1990, 29:339-360

125. Archer M, Hand SJ, Godthelp H, Creaser P: Correlation of the Cainozoic sediments of the Riversleigh World Heritage fossil property, Queensland, Australia. Mémoires et Travaux de l'Institut de Montpellier de l'Ecole Pratique des Hautes Etudes 1997, 21:131-152.

126. Archer M, Derrick AA, Bassarova M, Beck RMD, Black K, Boles WE, Brewer $P$, Cooke BN, Crosby K, Gillespie A, Godthelp H, Hand SJ, Kear BP, Louys J, Morrell A, Muirhead J, Roberts KK, Scanlon JD, Travouillon KJ, Wroe S: Current status of species-level representation in faunas from selected fossil localities in the Riversleigh World Heritage Area, northwestern Queensland. Alcheringa 2006, 301:1-17.

127. Clyde WC, Sheldon ND, Koch PL, Gunnell GF, Bartels WS: Linking the Wasatchian/Bridgerian boundary to the Cenozoic Global Climate Optimum: new magnetostratigraphic and isotopic results from South Pass, Wyoming. Palaeogeog Palaeoclim Palaeoecol 2001, 167:175-199.

128. Conrad JL, Rieppel O, Grande L: A Green River (Eocene) polychrotid (Squamata: Reptilia) and a re-examination of iguanian systematics. J Paleontol 2007, 81:1365-1373.

129. Wang XL, Zhou ZH: Mesozoic Pompei. In The Jehol Biota. Edited by Chang MM, Chen PJ, Wang YQ, Wang Y. Shanghai: Shanghai Scientific and Technical Publishers; 2003:19-35.

130. Evans SE, Wang Y: The Early Cretaceous lizard Dalinghosaurus from China. Acta Pal Pol 2005, 50:725-742.

131. Near TJ, Sanderson MJ: Assessing the quality of molecular divergence time estimates by fossil calibrations and fossil-based model selection Phil Trans R Soc B 2004, 359:1477-1483.

132. Haeckel E: Generelle Morphologie der Organismen. Zweiter Band: Allgemeine Entwicklungsgeschichte der Organismen. Berlin: Georg Reimer; 1866.

133. Günther A: Contribution to the anatomy of Hatteria (Rhynchocephalus, Owen). Phil Trans R Soc Lond 1867, 157:1-34

134. Cooper JS, Poole DFG, Lawson R: The dentition of agamid lizards with special reference to tooth replacement. J Zool 1970, 162:85-98.

135. Evans SE: Tooth replacement in the Lower Jurassic lepidosaur Gephyrosaurus bridensis. Neues Jahrb Geol Paläontol Abh 1985, 1985:411-420.

136. Fraser NC: The osteology and relationships of Clevosaurus (Reptilia: Sphenodontida). Phil Trans R Soc B 1988, 321:125-178.

137. Renesto S: A sphenodontid from the Norian (Late Triassic) of Lombardy (Northern Italy): a preliminary note. Mod Geol 1995, 20:149-158.

138. Jones MEH: Dentary tooth shape in Sphenodon and its fossil relatives (Diapsida: Lepidosauria: Rhynchocephalia). Front Oral Biol 2009, 13:9-15.

139. Spencer PS, Benton MJ: Procolophonids from the Permo-Triassic of Russia. In The age of dinosaurs in Russia and Mongolia. Edited by Benton MJ, Shishkin MA, Unwin DM, Kurochkin EN. Cambridge, UK: Cambridge University Press; 2000:160-176.

140. Heckert AB, Spencer LG, Rinehart LF, Spielmann JP, Hunt AP, Kahle R: Revision of the archosauromorph reptile Trilophosaurus, with a description of the first skull of Trilophosaurus Jacobsi, from the Upper Triassic Chinle Group, West Texas, USA. Palaeontol 2006, 49:621-640.

141. Macdougall MJ, Modesto SP: New information on the skull of the Early Triassic parareptile Sauropareion anoplus, with a discussion of tooth attachment and replacement in procolophonids. J Vertebr Paleontol 2011 31:270-278.

142. Milner AR, Gardiner BG, Fraser NC, Taylor MA: Vertebrates from the Middle Triassic Otter Sandstone Formation of Devon. Palaeontol 1990 33:873-892

143. Benton MJ, Warrington G, Newell AJ, Spencer PS: A review of Middle Triassic tetrapod assemblages. In In the shadow of the dinosaurs: Early 
Mesozoic tetrapods. Edited by Fraser NC, Sues H-D. Cambridge: Cambridge University Press; 1994:131-160.

144. Säilä LK: Alpha taxonomy of the Russian Permian procolophonoid reptiles. Acta Palaeontol Pol 2009, 54:599-608.

145. Vidal N, Hedges SB: The molecular evolutionary tree of lizards, snakes, and amphisbaenians. C R Biol 2009, 332:129-139.

146. Townsend TM, Mulcahy DG, Noonan BP, Sites JW, Kuczynskic CA, Wiens JJ, Reeder TW: Phylogeny of iguanian lizards inferred from 29 nuclear loci, and a comparison of concatenated and species-tree approaches for an ancient, rapid radiation. Mol Phylogenet and Evol 2011, 61:363-380.

147. Evans AR, Sanson GD: The effect of tooth shape on the breakdown of insects. J Zool Lond 1998, 246:391-400.

148. Fraser NC, Walkden GM: The ecology of a Late Triassic reptile assemblage from Gloucestershire, England. Palaeogeog Palaeoclimat Palaeolecol 1983, 42:341-365.

149. Jones MEH: The evolution of skull shape and feeding strategy in Rhynchocephalia (Diapsida: Lepidosauria). J Morphol 2008, 269:945-966.

150. Reynoso VH: Possible evidence of a venom apparatus in a middle Jurassic sphenodontian from the Huizachal red beds of Tamaulipas, México. J Vertebr Paleontol 2005, 25:646-654.

151. Davic RD, Welsh HH: On the ecological role of salamanders. Annu Rev Ecol Evol Syst 2004, 35:405-434

152. Nesbitt SJ, Sidor CA, Irmis RB, Angielczyk KD, Smith RMH, Tsuji LA: Ecologically distinct dinosaurian sister group shows early diversification of Ornithodira. Nature 2010, 464:95-98.

153. Butler RJ, Barrett PM, Abel RL, Gower DJ: A possible ctenosauriscid archosaur from the Middle Triassic Manda beds of Tanzania. J Vertebr Paleontol 2009, 29:1022-1031

154. Nesbitt SJ, Butler RJ: Redescription of the archosaur Parringtonia gracilis from the Middle Triassic Manda beds of Tanzania, and the antiquity of Erpetosuchidae. Geol Mag 2012, 150:225-238.

155. Cisneros JC, Damiani R, Schultz C, da Rosa A, Schwanke C, Neto LW, Aurélio PLP: A procolophonoid reptile with temporal fenestration from the Middle Triassic of Brazil. Proc R Soc Lond B 2004, 271:1541-1546.

156. Langer MC, Ribeiro AM, Schultz CL, Ferigolo J: The continental tetrapodbearing Triassic of south Brazil. In The Global Triassic, New Mex Mus Nat Hist Sci Bull. 41st edition. Edited by Lucas SG, Spielman JA. Albuquerque: New Mexico Museum of Natural History and Science; 2007:201-218.

157. Rogers RR, Arcucci AB, Abdala F, Sereno PC, Forster CA, May CL: Paleoenvironment and taphonomy of the Chañares Formation tetrapod assemblage (Middle Triassic), Northwestern Argentina: spectacular preservation in volcanogenic concretions. Palaois 2001, 16:461-481.

158. Nesbitt SJ: Arizonasaurus and its implication for archosaur divergence. Proc Roy Soc B 2003, 17:9-47.

159. Nesbitt SJ: Osteology of the Middle Triassic pseudosuchian archosaur Arizonasaurus. Hist Biol 2005, 17:9-47.

160. Bandyopadhyhy S, Sengupta D: Middle Triassic vertebrates of India. J Afr Earth Sci 1999, 29:233-241.

161. Sen K: A new rauisuchian archosaur from the Middle Triassic of India. Palaeontol 2005, 48:185-196.

162. Catuneanu O, Wopfner H, Eriksson PG, Cairncross B, Rubidge BS, Smith RMH, Hancox PJ: The Karoo basins of south-central Africa. J Afr Earth Sci 2005, 43:211-253.

163. Nicolas M, Rubidge BS: Changes in Permo-Triassic terrestrial tetrapod ecological representation in the Beaufort Group (Karoo Supergroup) of South Africa. Lethaia 2010, 43:45-59.

164. Liu J: Parakannemeyeria chengi sp. nov. from the Kelamayi Formation of Jimusar, Xinjiang. Vertebr Palasiat 2004, 42:77-80.

165. Gao K-Q, Fox RC, Zhou C-F, Li D-Q: A new nonmammalian eucynodont (Synapsida: Therapsida) from the Triassic of Northern Gansu Province, China, and its biostratigraphic and biogeographic Implications. Am Mus Nov 2010, 3685:1-25

166. Kalandadze NN, Sennikov AG: New reptiles from the Middle Triassic of the Cis- Urals. Paleontol J 1985, 1985(2):77-84

167. Abdala F, Smith RMH: A Middle Triassic cynodont fauna from Namibia and its implications for the biogeography of Gondwana. J Vertebr Palaentol 2009, 29:837-851.

168. Fröbisch J, Angielczyk KD, Sidor CA: The Triassic dicynodont Kombuisia (Synapsida, Anomodontia) from Antarctica, a refuge from the terrestrial Permian-Triassic mass extinction. Naturwissenschaften 2010, 97:187-196.
169. Jalil N: Sur deux crânes des petits Sauria (Amniota, Diapsida) du Trias moyen d'Algerie. C R Acad Sci Paris 1990, 311:731-736.

170. Fortuny J, Galobart A, Santisteban C: A new capitosaur from the Middle Triassic of Spain and the relationships within the Capitosauria. Acta Palaeontol Polon 2011, 56:553-566.

171. Evans SE, Borsuk-Białynicka M: A stem-group frog from the Early Triassic of Poland. Acta Palaeont Pol 1998, 43:573-580.

172. Evans SE, Milner AR, Mussett F: The earliest known salamanders (Amphibia, Caudata) a record from the Middle Jurassic of England. Geobios 1988, 21:539-552.

173. Skutschas PP, Krasnolutskii SA: A new genus and species of basal salamanders from the Middle Jurassic of Western Siberia, Russia. Proc Zool Inst RAS 2011, 315:167-175.

174. Jenkins FA, Walsh DM, Carroll RL: Anatomy of Eocaecilia micropodia, a limbed caecilian of the Early Jurassic. Bull Mus Comp Zool 2007, 158:285-365.

175. Gardner JD, Evans SE, Sigogneau-Russell D: New albanerpetontid amphibians from the Early Cretaceous of Morocco and Middle Jurassic of England. Acta Pal Polonica 2003, 48:301-319.

176. Matsumoto R, Evans SE: Choristoderes and the freshwater assemblages of Laurasia. J Iberian Geol 2010, 36:253-274.

177. Anderson JS, Reisz RR, Scott D, Fröbisch NB, Sumida SS: A stem batrachian from the Early Permian of Texas and the origin of frogs and salamanders. Nature 2008, 453:515-518.

178. San Mauro D: A multilocus timescale for the origin of extant amphibians. Mol Phylogenet Evol 2010, 56:554-561

179. Magallón SA: Dating lineages: molecular and paleontological approaches to the temporal framework of clades. Int J Plant Sci 2004, 165:7-21.

180. Nesbitt SJ: The early evolution of archosaurs: relationships and the origin of major clades. Bull Am Mus Nat Hist 2011, 352:1-292.

181. Evans SE, Prasad GVR, Manhas BK: Rhynchocephalians (Reptilia : Lepidosauria) from the Mesozoic Kota Formation of India. Zool J Linn Soc 2001, 133:309-334.

182. Thorne JL, Kishino H, Painter IS: Estimating the rate of evolution of the rate of molecular evolution. Mol Bio Evol 1998, 15:1647-1657.

183. Anderson CL: Dating divergence times in phylogenies. In PhD thesis, Digital Comprehensive Summaries of Uppsala Dissertations from the Faculty of Science and Technology. Uppsala: Acta Universitatis Upsaliensis; 2007.

184. Himmelman L, Metzler D: TreeTime: an extensible C++ software package for Bayesian phylogeny reconstruction with time-calibration. Bioinformatics 2009, 25:2440-2441.

185. Nesbitt SJ, Barrett PM, Werning S, Sidor CA, Charig AJ: The oldest dinosaur? A Middle Triassic dinosauriform from Tanzania. Biol Lett 2013, 9. http://rsbl.royalsocietypublishing.org/content/9/1/20120949.

186. Upchurch P: Gondwanan break-up: legacies of a lost world? Tren Ecol Evol 2008, 23:229-236.

187. Carranza S, Arnold EN, Mateo JA, López-Jurado LF: Long-distance colonization and radiation in gekkonid lizards, Tarentola (Reptilia: Gekkonidae), revealed by mitochondrial DNA sequences. Proc $R$ Soc $B$ 2000, 267:637-649.

188. Calsbeek R, Smith TB: Ocean currents mediate evolution in island lizards. Nature 2003, 426:552-555.

189. De Queiroz A: The resurrection of oceanic dispersal in historical biogeography. Trends Ecol Evol 2005, 20:68-73.

190. Vidal N, Azvolinsky A, Cruaud C, Hedges SB: Origin of tropical American burrowing reptiles by transatlantic rafting. Biol Lett 2008, 4:115-118.

191. Goswami A, Upchurch P: The dating game: a reply to Heads (2010). Zool Scripta 2010, 39:406-409.

192. Milner AC, Milner AR, Evans SE: Global changes and biota: amphibians, reptiles and birds. In Biotic Response to Global Change: the last 145 million years. Edited by Culver S, Rawson P. Cambridge, UK: Cambridge University Press; 2000:316-332.

193. Apesteguía S, Rougier GW: A Late Campanian sphenodontid maxilla from northern Patagonia. Am Mus Nov 2007, 3581:1-11.

194. Gamble T, Bauer AM, Colli GR, Greenbaum E, Jackman TR, Vitt LJ, Simons AM: Coming to America: multiple origins of New World geckos. J Evol Biol 2011, 24:231-244.

195. Arnold EN, Poinar G: A 100 million year old gecko with sophisticated adhesive toe pads, preserved in amber from Myanmar. Zootaxa 1847, 2008:62-68.

196. Alifanov VR: The most ancient gekkos (Lacertilia: Gekkonidae) from the Lower Cretaceous of Mongolia. Paleontol Zh 1989, 1:57-74. 
197. Daza JD, Alifanov VR, Bauer AM: A redescription and phylogenetic reinterpretation of the fossil lizard Hoburogekko suchanovi Alifanov, 1989 (Squamata, Gekkota), from the Early Cretaceous of Mongolia. J Vertebr Paleontol 2012, 32:1302-1312

198. Gamble T, Greenbaum E, Jackman TR, Russell AP, Bauer AM: Repeated origin and loss of adhesive toepads in geckos. PLOS ONE 2012, 7(6):e39429.

199. Renesto S, Bernardi M: Redescription and phylogenetic relationships of Megachirella wachtleri Renesto et Posenato, 2003 (Reptilia, Diapsida). Paläontol Zeit. in press 10.1007/s12542-013-0194-0.

doi:10.1186/1471-2148-13-208

Cite this article as: Jones et al:: Integration of molecules and new fossils supports a Triassic origin for Lepidosauria (lizards, snakes, and tuatara). BMC Evolutionary Biology 2013 13:208.

\section{Submit your next manuscript to BioMed Central and take full advantage of:}

- Convenient online submission

- Thorough peer review

- No space constraints or color figure charges

- Immediate publication on acceptance

- Inclusion in PubMed, CAS, Scopus and Google Scholar

- Research which is freely available for redistribution 